\title{
Democratic Republic of Timor-Leste: Public Financial Management-Performance Report
}

This public financial management performance report on Timor-Leste was prepared by a staff team of the International Monetary Fund as background documentation for the periodic consultation with the member country. It is based on the information available at the time it was completed in August 2010. The views expressed in this document are those of the staff team and do not necessarily reflect the views of the government of Timor-Leste or the Executive Board of the IMF.

The policy of publication of staff reports and other documents by the IMF allows for the deletion of market-sensitive information.

Copies of this report are available to the public from

International Monetary Fund • Publication Services $70019^{\text {th }}$ Street, N.W. • Washington, D.C. 20431

Telephone: (202) 623-7430 • Telefax: (202) 623-7201

E-mail: publications@imf.org Internet: http://www.imf.org

\section{International Monetary Fund Washington, D.C.}




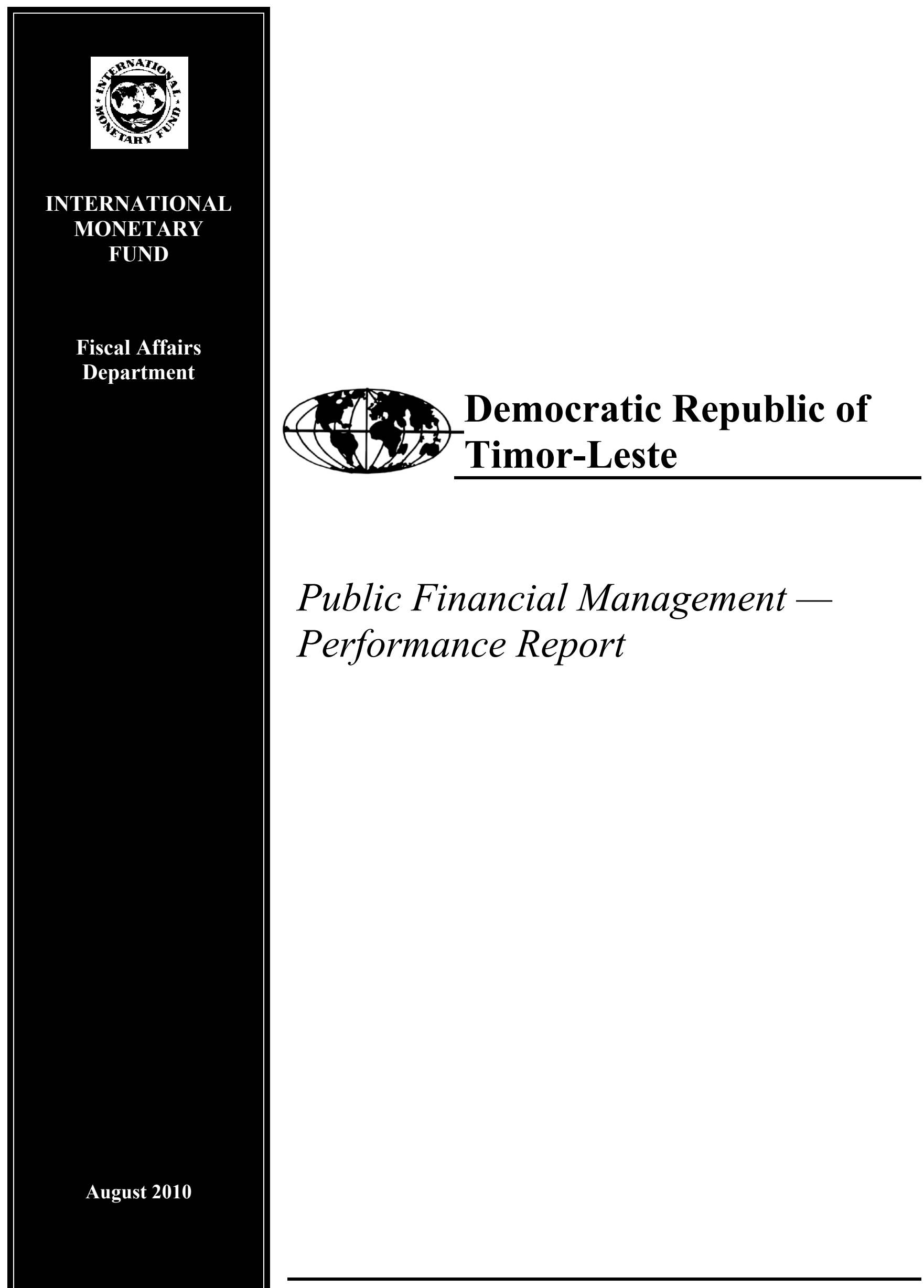





\section{INTERNATIONAL MONETARY FUND}

Fiscal Affairs Department

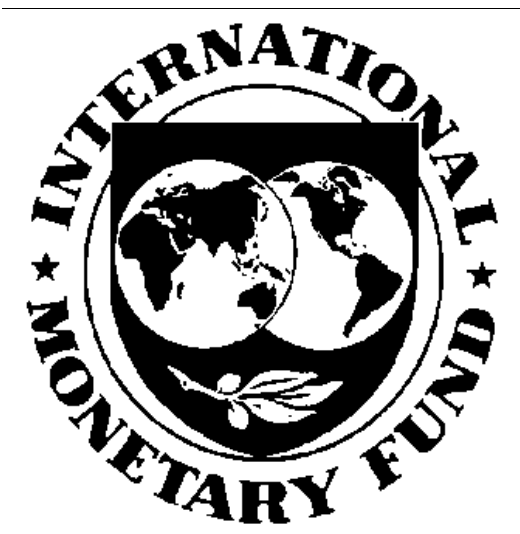

\section{DEMOCRATIC REPUBLIC OF TIMOR-LESTE}

Public Financial Management - Performance Report

Holger van Eden, Franck Bessette, Eliko Pedastsaar, and Hari Nayer

August 2010 
The contents of this report constitute technical advice provided by the staff of the International Monetary Fund (IMF) to the authorities of a Timor-Leste (the "TA recipient") in response to their request for technical assistance. This report (in whole or in part) or summaries thereof may be disclosed by the IMF to IMF Executive Directors and members of their staff, as well as to other agencies or instrumentalities of the TA recipient, and upon their request, to World Bank staff and other technical assistance providers and donors with legitimate interest, unless the TA recipient specifically objects to such disclosure (see Operational Guidelines for the Dissemination of Technical Assistance Informationhttp://www.imf.org/external/np/pp/eng/2009/040609.pdf).

Disclosure of this report (in whole or in part) or summaries thereof to parties outside the IMF other than agencies or instrumentalities of the TA recipient, World Bank staff, other technical assistance providers and donors with legitimate interest shall require the explicit consent of the TA recipient and the IMF's Fiscal Affairs Department. 


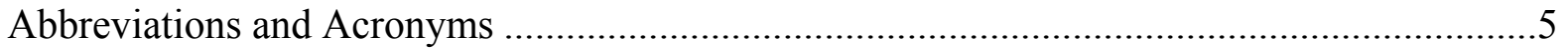

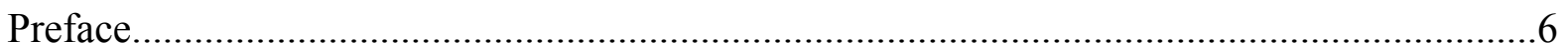

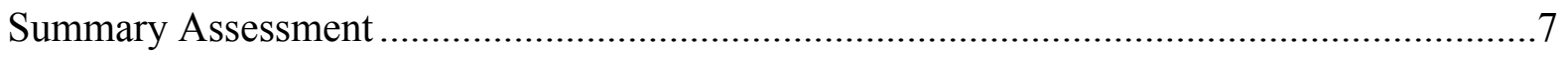

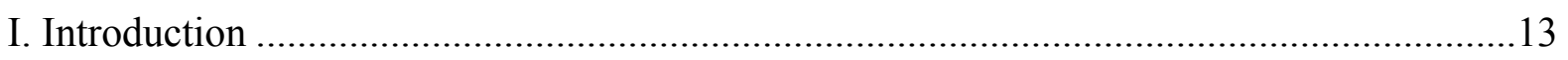

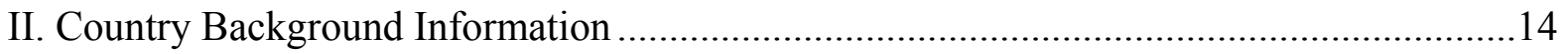

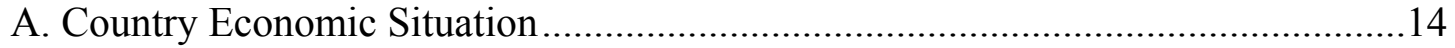

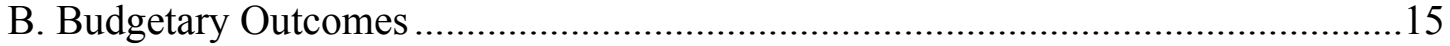

C. Legal and Institutional Framework for PFM.................................................... 18

III. Assessment of PFM Systems, Processes, and Institutions...........................................19

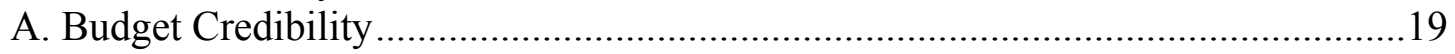

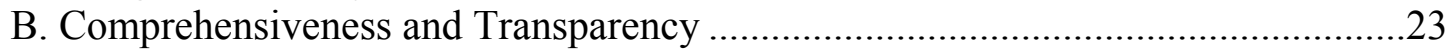

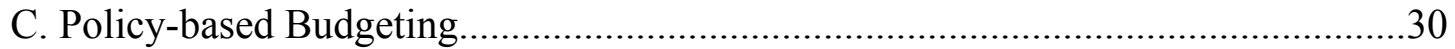

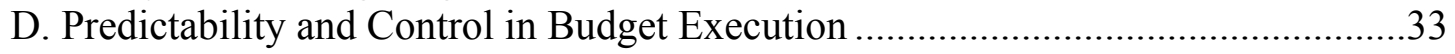

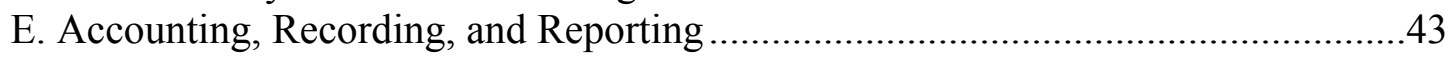

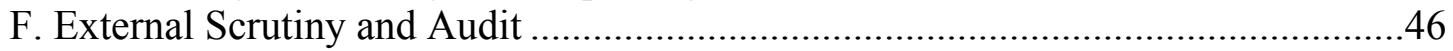

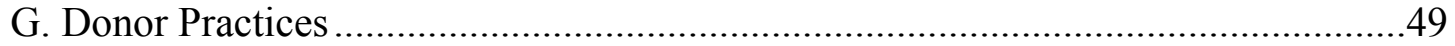

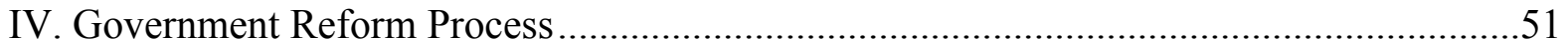

Tables

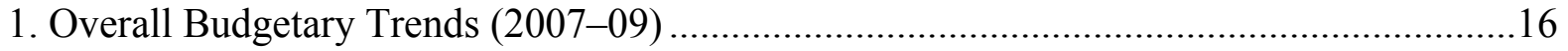

2. Government Expenditures by Economic Classification ...............................................17

3. Comparison Between Original and Actual Budget Expenditure ....................................20

4. Comparison Between Original and Actual Budget Revenue.........................................22

5. Comprehensiveness of Budget Documentation ..........................................................25

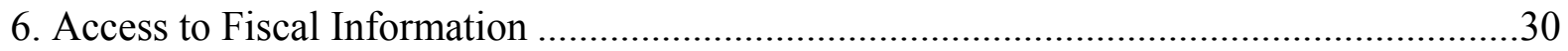

\section{Boxes}

1. The Public Financial Management Capacity Building Project .......................................52

Annexes Tables

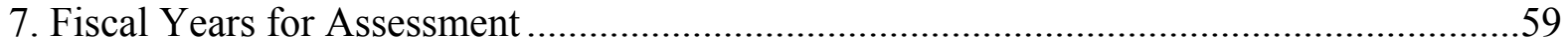

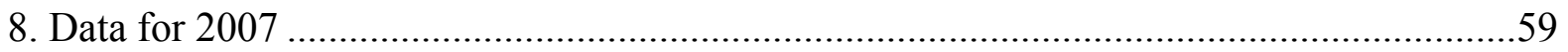

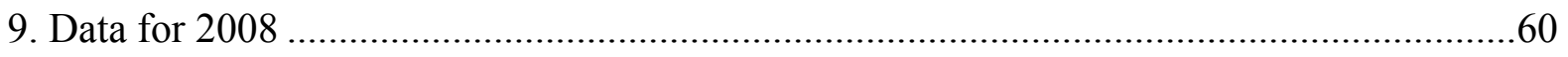

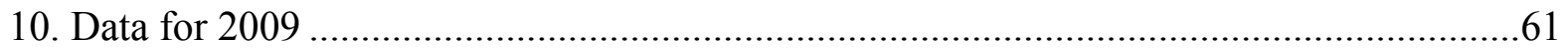

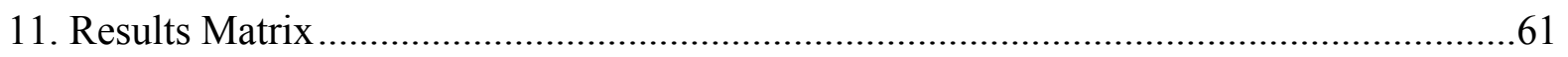


Annexes

I. PFM-PR Summary Table .54

II. Background Documents and Previous Analytical Work..............................................58

III. Calculation Sheet for PFM Performance Indicator PI-2 ...............................................59 


\section{Abbreviations AND ACRONYMS}

\begin{tabular}{|c|c|}
\hline AAP & Annual Action Plan \\
\hline $\mathrm{ADB}$ & Asian Development Bank \\
\hline AGA & Autonomous Government Agency \\
\hline ANP & National Petroleum Authority (Agência Nacional do Petróleo) \\
\hline APORTIL & Port Authority (Autoridade Portuária) \\
\hline BFML & Budget and Financial Management Law \\
\hline BPA & Banking and Payment Authority (Central Bank) \\
\hline COFOG & Classification of Functions of Government \\
\hline $\mathrm{COM}$ & Council of Ministers \\
\hline $\mathrm{CPV}$ & Commitment and Payment Voucher \\
\hline EDTL & Electricity of Timor-Leste \\
\hline ESI & Estimated Sustainable Income \\
\hline FAD & Fiscal Affairs Department \\
\hline GDRC & General Directorate of Revenue and Customs \\
\hline GFS & Government Finance Statistics \\
\hline GFSM & Government Finance Statistics Manual \\
\hline GG & General Government \\
\hline HATAC & High Administrative, Tax, and Audit Court \\
\hline IFMIS & Integrated Financial Management Information System \\
\hline IGO & Inspector General Office \\
\hline IMfTL & Microfinance Institution \\
\hline INTOSAI & International Organization of Supreme Audit Institutions \\
\hline JPDA & Joint Petroleum Development Area \\
\hline MOF & Ministry of Finance \\
\hline NDAE & National Directorate of Aid Effectiveness \\
\hline PEFA & Public Expenditure and Financial Accountability \\
\hline PFM & Public Financial Management \\
\hline PFMCBP & Public Financial Management Capacity Building Project \\
\hline ROSC & Report on the Observance of Standards and Codes \\
\hline RTTL & Radio and Television of Timor-Leste (Radio e Televisão de Timor-Leste) \\
\hline SAMES & Autonomous Service for Drugs and Health Equipment \\
\hline SDP & Strategic Development Plan \\
\hline TIN & Taxpayer Identification Number \\
\hline TLS & Democratic Republic of Timor-Leste \\
\hline TSA & Treasury Single Account \\
\hline UNTAET & United Nations Transitional Administration of East Timor \\
\hline WB & World Bank \\
\hline
\end{tabular}




\section{Preface}

In 2009, the Ministry of Finance of Timor-Leste (TLS) requested the IMF Fiscal Affairs Department (FAD) to lead a Public Expenditure and Financial Accountability (PEFA) assessment to evaluate the strengths and weaknesses of the Public Financial Management (PFM) system, and provide a performance benchmark to measure progress with PFM reforms and evaluate if a reorientation of the ongoing PFM effort was needed. The PEFA assessment was part of a more comprehensive diagnostic package, comprising also a fiscal transparency assessment against the IMF's Code of Fiscal Transparency, a so-called fiscal ROSC. The PEFA methodology provides a framework for governments and other stakeholders to assess the PFM system in a country. The assessment is based on a standardized format and indicator set developed by a multi-donor group, including the World Bank (WB), the IMF, the EU, and several bilateral donors. Almost 100 countries have carried out PEFA assessments so far.

The PEFA exercise was led by the IMF, but the ministry of finance (MOF), the WB, and the Asian Development Bank (ADB) participated fully in the exercise. Staff of the MOF was trained in advance in the PEFA methodology during the IMF's fiscal ROSC mission in JanuaryFebruary 2010. Multiple discussion sessions where held with MOF staff to jointly evaluate the scoring of various indicators.

To supplement interviews with government officials and representatives of civil society and the private sector held during the fiscal ROSC, the PEFA mission benefited from further discussions with the Minister of Finance, Mrs. Emilia Pires, the Vice-Minister of Finance, the Director General of Finance, the National Director of the treasury, the National Director of the Budget, the General Directorate of Revenues and Customs, and staff from the Ministries of Education, Infrastructure, and Health. The mission also interviewed international advisors of the World Bank's PFMCBP program and met with the donor community in Dili. Special thanks are due to Mr. Peter Wild, international advisor for the National Budget Directorate for his patience in answering many detailed questions on the TLS budget system.

The PEFA team visited Dili in May-June 2010 and was led by Holger van Eden (head, FAD) and comprised Franck Bessette, Eliko Pedastsaar (all FAD) and Hari Nayer (FAD treasury resident advisor). Mario Pessoa (FAD) provided valuable support from IMF HQ. From the WB, Imad Saleh, and from ADB Hayden Everett contributed to the assessment.

In addition to this report the PEFA team organized a seminar on redirection of the PFM reform strategy, based on the PEFA and Fiscal ROSC findings. 


\section{SUMMARY ASSESSMENT}

Timor-Leste has weathered the global financial crisis well and has experienced healthy economic growth rates exceeding 12 percent per year. The source of economic growth, petroleum, has been in production in the Timor Sea only since 2004. Petroleum revenues have been channeled to the public sector through a well-managed and supervised Petroleum Fund which limits the transfers to the budget to a sustainable level so that future generations will also benefit from the petroleum wealth and the absorption capacity of the domestic economy is not exceeded.

After emerging from a long independence struggle and internal conflict, the country is now engaged in an ambitious development strategy aimed at elevating the population out of poverty and providing a basis for growth of the non-oil economy. Government expenditures have grown very fast in the past three years, with growth rates of over 25 percent. The public financial management (PFM) system, and its appropriate use, will be important determinants of the effectiveness and sustainability of the present expenditure programs, and their ability to deliver on the goals set by the government. For that reason, the previous and present governments have invested heavily, with support of the donor community, in strengthening PFM institutions, systems, and capacities.

Overall, Timor-Leste has made solid progress in strengthening PFM systems in just a very few years. This PEFA assessment focuses on the PFM performance over the period 2007-10. An initial assessment led by the EC took place in 2007. Improvements were measured in 12 of the 29 applicable indicators. The improvements are often modest, but underpinned by real changes in work practices, legislation, and IT systems. Most notable are the gains made in the comprehensiveness of fiscal information, fiscal transparency, funding predictability, and timeliness and quality of bank reconciliation and financial statements. Legislative scrutiny and the external audit process also improved somewhat. The assessment also reveals that on several indicators the 2007 PEFA assessment was overly positive on the outcomes. This leads to real accomplishments not being reflected in higher indicator scores.

\footnotetext{
Substantial weaknesses in the PFM system remain. The relative strengths of the MOF are diminished by gaps in the PFM system elsewhere. An independent, external auditor is missing, internal audit is almost non-existent, the budget coverage is incomplete, and budget planning and implementation capacity in line ministries are still weak. There has been some slippage in performance also, as this PEFA exercise shows, for example on orderliness of the budget process, development of sectoral investment strategies, multiyear budgeting, and procurement. While not measured directly, the dependence of the PFM system on foreign international experts is still large, and issues of integrity in procurement and tax administration remain a concern with regard to the overall effectiveness of the public administration.
} 


\section{Main findings}

The budget is not a good predictor of aggregate expenditure outturn. This is caused on the one hand by repeated and large supplementary budgets, on the other hand by substantial under-execution of the budget (although major improvement has been made over the past two years). While reacting to economic emergencies is praiseworthy, large supplementaries should not be a recurring feature of PFM systems. In general, supplementary budgets have a weaker expenditure impact than thoroughly planned budgets because expenditure plans are not well developed. They also detract MOF and line ministry staff from focusing on the effective implementation of the regular budget. A basic principle of budgeting is the annuality principle: the budget decides on all government spending for the coming year. If supplementaries are the norm, budgets tend to leave out essential spending and become less credible, because the expectation is that a supplementary will address additional spending needs.

The indicator for the stable composition of expenditure scores quite well, the one measuring conservative estimation of revenues score does not. The composition indicator provides indication that the overall direction of expenditure in the original budget as approved by parliament is maintained despite the large supplementaries. Revenues could be projected at more realistic levels in some years. Transfers from the Petroleum Fund, which comprise most of domestic revenues, are a government decision and should thus, be reasonably assured. Nevertheless, changes to the planned transfer occur and can be quite sizeable. Expenditure arrears are limited, indicating credible budget planning and wellcontrolled execution. A definition of expenditure arrears in financial regulation would be welcome though. Entering of invoice dates by line ministries in the integrated financial management information system will then enable monitoring of arrears if they occur. This will help support budget credibility in the future and provide for more disciplined government payment behavior.

The budget document provides quite comprehensive information; fiscal transparency is relatively high. The budget provides necessary information on a range of issues including the government's main objectives, development strategy and programs, basic macroeconomic assumptions, fiscal balance, funding sources, and expenditure and revenues in various formats, as well as comparison to previous years' outturns. Expenditure data can be presented according to administrative, economic, and functional classifications. However, new policy and its costs are not well identified. Overall provision of fiscal information is quite good, with the main weaknesses being lack of information on government financial assets, contract awards resulting from procurement processes, and resources available to government primary service delivery units, such as schools.

The coverage of the budget could be more comprehensive. While full information is provided on the Petroleum Fund, and most government agencies are in fact still fully 
integrated in the budget, reporting on donor funded expenditure is quite weak. While donors provide estimates of commitments and expenditures for the budget, there is no joint evaluation and approval of state and donor funded expenditure, and in-year reporting by the government on donor funded expenditure is lacking. Donor funded expenditure is not reported on in the financial statements. Donors should be urged to provide information more frequently and better aligned with the TLS budget system. Integration into national systems should be on the agenda once an independent external auditor has been set up.

While autonomous agencies and public enterprises are relatively few in number, oversight of these entities is weak and the fiscal risk they represent is not monitored. MOF receives no regular reporting from autonomous agencies and public enterprises. A department within MOF has recently been set up for this purpose. Regulation on what parts of governments should be eligible for agency or public enterprise status, and on issues like reporting, audit, supervision, own revenues, and possible profit transfers requirements, should be further developed, standardized and not left to individual establishment laws. The budget documentation should provide a brief description of the State's financial involvement and risk towards this sector. While agency and enterprise status can improve service delivery, these vehicles are also often used to escape civil service wage constraints and budget discipline, and thus should be utilized with restraint.

The linkage between policy objectives and budget is weak as a program classification exists, but is not well linked to line ministry policies; sector investments programs are no longer developed. The few that still exist have weak linkages to future budget envelopes. The present initiative to invigorate strategic planning in the prime minister's office is very welcome. It should be followed by more detailed sectoral planning at the line ministry level. On the basis of national and sectoral planning prime minister's office, MOF and line ministries could develop over the medium-term a multiyear public investment plan of priority and much better-developed capital projects.

The orderliness of the budget process has diminished somewhat. For example, presently, the budget calendar does not allow line ministries enough time for preparation of investment projects. Line ministries only have two weeks to prepare their submissions for capital expenditure, and four weeks for their recurrent budget proposal. As no ceilings are set for line ministry capital expenditure in the budget circular, submissions are much too high and poorly developed. Project proposals lack projections of the recurrent cost implication for multiple years for maintenance and other recurrent expenditure items. These cost items are part of appropriate costing of public investment. The present practice of focusing strongly on new investment could lead to rapid deterioration of the public capital stock in the coming years. Given the already high pressures on the recurrent budget, maintenance budgets should be increased now.

The MOF lacks the time and capacity for adequate review of rationale, costing, and impact of public investment. The MOF, perhaps together with the new planning agency 
under the prime minister's office, should be allotted more time to review investment proposals on alignment with government priorities, appropriate costing and, for larger investments use of cost-benefit analysis (possibly on an outsourced basis) should be used to analyze expected societal benefits. The quality of public investment will to a large extent determine whether ambitions for development of the non-oil economy will be realized.

Fiscal and budgetary policies lack a solid medium-term perspective. Macroeconomic projections are not extended to the medium term and there is no medium-term fiscal framework that could act as frame for medium-term expenditure plans. There are incremental estimates of recurrent budget expenditure, but these do not mean much if they are not aligned with growth and inflation estimates and the cost drivers of government policies. As a starting point for including a multiyear perspective it would make sense for the macro unit in MOF to start providing medium-term macrofiscal projections.

Transparency of tax payer obligations has improved but other aspects of tax collection remain weak or have even degraded. The information on domestic and petroleum tax legislation on the MOF's website has improved. Information is now provided in multiple languages, including in some cases Tetum and English. Compliance is a major issue in domestic tax collection, however. While tax penalties are broadly appropriate, noncompliance is not followed through vigorously. Both by the administration and the judiciary, a new focus on tax compliance should be pursued. Capacities in tax audit are very low. There are no annual work programs, limited to no risk-based selection criteria, and low technical and staff capacity. This is especially worrisome for the large sums collected through the Petroleum Tax Directorate. No audits have been carried out here for over two years. Access to petroleum companies incorporated in Australia is a priority, as is coordination and information sharing with the National Petroleum Authority (ANP) which is responsible for collection of royalties.

Cash flow planning and predictability of funding for line ministries and agencies have improved considerably. A cash flow plan is prepared annually and updated quarterly or when needed. This provides assurances for the smooth execution of the budget. The assured transfer from the Petroleum Fund is of course also very helpful in this. It has allowed the treasury to release to line ministries their full budget appropriation at the start of the year.

Budget execution has been further enhanced recently by a very flexible, but perhaps too

flexible, new virement framework. This new framework has replaced a framework in which MOF provided very tight control over the approved budget at the line item level. On the basis of this the PEFA sub-indicator for virement (in PI - 16) still scored quite low. The new framework basically allows virement over all institutional budget entities within line ministries, with some limitations of virement over the four major economic expenditure categories in line ministries. While a more flexible virement regime was needed, the question arises if the new framework will not lead to less disciplined budget preparation, and less policy control of the legislature over the expenditure direction of the budget. 
The payments system is greatly supported by a well-functioning Treasury Single Account (TSA). Further consolidation of commercial bank accounts of line ministries should have high priority, however. Future decentralized spending in a small country like TLS should be executed through an expanded but still centralized payment and accounting system facilitated by the treasury. This will enhance integrity and efficiency of processes greatly.

Procurement has been in state of flux for many years. While considerable capacity has been built both in MOF and in line ministries, the new institutional setting at the vice prime minister's office bears new challenges for coordination, supervision, and implementation. The extent of the use of competitive bidding as standard procurement instrument is not measured. Counterparts indicate that less competitive instruments, such as single sourcing and use of quotations, are becoming more prevalent, and are often legitimized by ad hoc decree legislation. Moreover the use of exceptions to the legal regime is reportedly not always well argued. The appeals regime misses an independent arbiter.

Solid progress has been made in expanding the functionality of the treasury system including the FreeBalance system. Timeliness and regularity of accounts reconciliation have improved markedly in the past three years. Quality and timeliness of in-year fiscal reports and financial statements have also steadily improved, but further strengthening of the reporting functionality of the Integrated Financial Management Information System (IFMIS) system (FreeBalance) should be pursued. Payroll integrity remains a concern, as does the effectiveness of internal controls at the line ministry level. System integrity at the treasury level is high, but uncertainty on what and when data is inputted by line ministries provides risk to accounting and payment processes.

Internal and external audit form the largest gaps in the present PFM system. The choice to have an external commercial auditor perform a financial audit of government accounts has been a very good one. However, the present external audit has serious limitations as it hardly look at the processes in line ministries. Also, the present audit is no substitute for a truly independent audit process as foreseen in the Constitution. Internal audit processes, similarly, have hardly been set up. Internal audit (PI-21) scores the lowest score possible. In the next phase of PFM reform capacity building in audit should definitely be an important component. MOF would be well-advised to lead the internal audit development process, and have crossministry responsibility for work programs, standards and capacity building.

Legislative scrutiny of the budget is slowly improving, but the discussion of the government audit report is still quite marginal. The reviews of the budget take place through an orderly process and aside from the prime minister and minister of finance, other ministers are now defending their expenditure proposals. Parliament could be briefed earlier in the year on the overall direction of government spending and on the macrofiscal environment. The review of the audit report should get a separate slot on parliament's agenda. Reviewing past performance is just as much part of the legislature's mandate as approving new expenditure. 


\section{The Government Reform Agenda}

This present PEFA assessment comes at a time that the MOF is reviewing its major multidonor funded PFM capacity building program. The WB has been asked by the government to develop a Strategic Action Plan for the MOF. This PEFA exercise, led by the IMF and with participation of the WB and ADB, can feed into this Strategic Action Plan. The recently prepared fiscal ROSC can also fulfill that role especially from the fiscal transparency perspective. PFM reform is a process that should be broader, though than MOF alone. Line ministries have until now not fully participated in the PFM reform agenda.

A natural tendency of governments is to try to address all the weaknesses identified in exercises like the PEFA. However, the temptation to address everything should be resisted: priorities, sequencing and consolidating present achievements should be part of any reform strategy. Capacity transfer has been weak up to now and should be a priority area as well. Major gaps in the overall PFM system such as internal and external audit will have to be addressed in any case. With regard to reforms in fiscal, budget, treasury management, audit, and tax, the assessment team has developed a discussion note that proposes a strategy focused on consolidation of existing reforms (to reap their full benefits), building of local staff capacity (while maintaining international advisors in force for the foreseeable future), adapting to new political priorities (such as decentralization), and very cautiously selecting a few new essential reforms.

For the government, buy-in and long-term commitment from the development partners will be essential. PFM development is a process measured in decades. The present PEFA bears out that the government has made solid progress in recent years. PFM processes are intertwined in crucial ways with the process of development. It would seem worthwhile to support further these processes which are so essential for sustainable development. 


\section{INTRODUCTION}

1. The purpose of this PEFA assessment is to evaluate the performance of the PFM system in TLS based on the PEFA indicators. ${ }^{1}$ It also measures the progress made since the last PEFA assessment in February 2007 led by the European Commission. This PEFA assessment aims to support a better understanding of the overall environment of the budget process and assist in identifying those parts of the PFM systems most in need of reform. The assessment should also constitute a common pool of information about the current status of PFM performance shared by the government of TLS and the international donor community. This PEFA assessment is part of a more comprehensive diagnostic framework comprising also a fiscal ROSC assessment. An IMF team prepared a Report on the Observance of Standards and Codes (ROSC) in January-February 2010 covering the transparency aspects of public finance with respect to the IMF's Fiscal Transparency Code. Synergies and complementarities between the fiscal ROSC and the PEFA were systematically sought during the PEFA assessment. This diagnostic work will be the basis for IMF's input in the elaboration by the government of TLS of a comprehensive PFM reform strategy.

2. This report is the result of a coordinated effort of the authorities, the IMF, WB, and ADB. A FAD Team of the IMF led by Holger van Eden and comprising Mario Pessoa, Franck Bessette, Eliko Pedastsaar, and Hari Nayer (FAD treasury resident advisor) visited the country in January-February 2010 for two weeks to (i) collect information for both the fiscal ROSC and the PEFA; (ii) prepare the ROSC report; (iii) train MOF and donor staff on the PEFA methodology; and (iv) set up a PEFA working group among MOF staff to conduct a self-assessment based on the PEFA indicators. A second mission was conducted in MayJune 2010 for two weeks to (i) finalize the PEFA assessment in discussion and consultation with the PEFA working group; (ii) present the results to relevant stakeholders; and (iii) discuss, based on the draft PEFA and ROSC reports, inputs to a PFM reform strategy.

3. The focus of the performance indicator set is public finance management at the central government level, including the related oversight institutions. Public enterprises, financial and nonfinancial, are outside the boundary of government and outside the scope of this assessment, except as they affect overall fiduciary risk. During 2007-10 subnational governments had not yet been established, and only one extra-budgetary fund existed.

\section{Information was gathered through a combination of in-depth interviews and} analysis of publicly available data and reports. A series of meetings and communications was conducted with officials from the MOF, various line ministries and other institutions, including representatives of international cooperation agencies, civil society, parliament, and

\footnotetext{
${ }^{1}$ The PEFA indicators are a set of 28 high level performance indicators that measure strengths and weaknesses of a government's PFM system, plus 3 high level performance indicators that measure the performance of international partners cooperating in the government's development efforts. The PEFA exercise has been carried out in more than 100 countries; more than 50 (now mostly repeat) assessments take place every year.
} 
other relevant administrative units. The team met on several occasions and conducted thorough discussions with the minister of finance and her team.

\section{COUNTRY BACKGROUND INFORMATION}

\section{A. Country Economic Situation}

5. TLS became the first new state of the $21^{\text {st }}$ century on May 20, 2002 following four hundred years of colonization and a quarter century of occupation and conflict. TLS is situated on the eastern part of the island of Timor, and includes also the enclave of Oecussi (in West-Timor) and the islands of Ataúro and Jaco. The population is around 1 million, with about half of them below the age of 17 . However, given the high birth rate, the demographic projections indicate that the population will triple by $2050 .^{2}$

6. The Timorese economy has been growing rapidly over the last few years and TLS is now a lower-middle-income economy. A marked improvement in security conditions, a rebound in agriculture from a 2007 drought, and a sharp increase in public expenditure have led to rapid economic growth since the civil unrest in 2006-07. Non-oil real GDP growth reached almost 13 percent in 2008. However, TLS still remains one of the least developed countries in the world, with 50 percent of the population living in poverty in 2007. Private investment in the non-oil sector remains at very low levels and growth is still mainly driven by public spending, complicating the prospects for broad-based growth. The country also continues to suffer the aftereffects of a decades-long independence struggle against Indonesia, which severely damaged infrastructure and displaced thousands of civilians.

\section{Although agriculture dominates TLS's non-oil economy and the livelihoods of} the majority of Timorese, TLS's petroleum reserves are the key to the country's prosperity. Agriculture makes up 30 percent of non-oil GDP, and 80 percent of the population is dependent on agriculture, forestry, and fisheries for their livelihoods. But agricultural productivity is low and quality problems hinder exports. Petroleum is now by far the largest source of income, and the government has developed a very modern and transparent legal and institutional structure to manage and safeguard the newly found wealth. All petroleum resources are managed by the Petroleum Fund established in 2005. This fund had accumulated financial assets of US\$5.3 billion by the end of 2009 .

8. The global crisis has had limited immediate impact on TLS. The key channels through which the crisis has spread across the globe - trade, investment, and finance- have played little role in TLS. As in other oil exporting countries, the key adverse impact of global

\footnotetext{
${ }^{2}$ Policy Note on Population Growth and its Implications in TLS, WB (2008).
} 
crisis has been through lower oil prices and a fall in petroleum revenues, which has, however, partially rebounded.

9. The key policy challenge for TLS is to manage its petroleum wealth in a sustainable fashion that stimulates the growth of the non-oil sector and supports poverty reduction. The main long-term strategic document was the Vision 2020 Plan initially prepared in 2005. After the current government stepped into office in 2007, a review of the Vision 2020 was initiated to update the plan. During period 2008-10 the government defined each year their priorities as a strategic guidance for the budget formulation process (six priorities for 2008, and seven for 2009 and 2010). These priorities have varied considerably over time reflecting TLS's rapidly changing recent circumstances.

10. Early 2010 the government defined a new Strategic Development Plan (SDP). It covers the period 2011-30, and is based on strengthening the State, fostering civic participation, and translating the nation's shared values into tangible long-lasting benefits for all of its citizens. The four main challenges that the SDP will address are: urban-rural and regional imbalances, shortage of skilled human resources, fragile institutions of the state, and post-conflict mentality. Key objectives to be reached by 2030 are the following:

- $\quad$ Every child has access to free, compulsory and mandatory education through Grade 12;

- All Timorese are literate;

- All citizens have access to primary health care;

- No child perishes because of inadequate water supply, malnutrition, or lack of health care;

- $\quad$ Every citizen has the opportunity to acquire new skills based on 21 st-century technologies, such as wireless broadband, high-yield agriculture, and cutting edge health care delivery;

- Extreme poverty is eradicated through universal access to public services, ample job opportunities, and economic development in all regions.

\section{B. Budgetary Outcomes}

11. The overall budgetary trends in TLS reflect the considerable wealth provided by oil and gas but also the necessity to address pressing needs and secure social cohesion. Total government spending has increased from 23 percent of non-oil GDP in 2004 to 103 percent in 2009. The net present value of the country's proven petroleum wealth, comprising the Petroleum Fund balance and discounted future revenue streams, is estimated at about US\$16.7 billion, i.e., about US\$15,500 per capita, however most of this wealth is still in nonrenewable petroleum resources. The receipts of petroleum revenue have grown rapidly and so has the estimated sustainable income (ESI), which the government can transfer yearly 
from the Petroleum Fund to the budget. ${ }^{3}$ It has increased from US $\$ 103$ million (30 percent of non-oil GDP) in the budget year of 2005/06 budget to US\$512 million (about 87 percent of non-oil GDP) in the 2009. As the transfers from the Petroleum Fund now cover most of the expenditure, the budget is vulnerable to developments in oil prices and production. The key to the sustainable development and future growth for TLS is the pace of withdrawals from the Petroleum Fund.

Table 1. Overall Budgetary Trends (2007-09)

\begin{tabular}{|c|c|c|c|c|c|c|}
\hline & \multicolumn{2}{|c|}{$\begin{array}{c}2007 \text { (July 1-Dec 31) } \\
\text { Actual }\end{array}$} & \multicolumn{2}{|c|}{$\begin{array}{l}2008 \\
\text { Actual }\end{array}$} & \multicolumn{2}{|c|}{$\begin{array}{l}2009 \\
\text { Actual }\end{array}$} \\
\hline & \$US ('000) & $\begin{array}{l}\% \text { of non- } \\
\text { oil GDP }\end{array}$ & \$US ('000) & $\begin{array}{l}\% \text { of non- } \\
\text { oil GDP }\end{array}$ & \$US ('000) & $\begin{array}{l}\% \text { of non- } \\
\text { oil GDP }\end{array}$ \\
\hline Domestic Revenues & 23,243 & 5.8 & 70,537 & 14.1 & 86,210 & 14.6 \\
\hline Tax Revenue & 14,501 & 3.6 & 37,333 & 7.5 & 46,730 & 7.9 \\
\hline Non tax revenue & 8,742 & 2.2 & 33,204 & 6.7 & 39,480 & 6.7 \\
\hline Total Expenditure & 64,336 & 16.2 & 483,873 & 97.0 & 605,340 & 102.6 \\
\hline Recurrent Expenditure & 63,609 & 16.0 & 397,405 & 79.6 & 433,648 & 73.5 \\
\hline Capital and Development & 727 & 0.2 & 86,468 & 17.3 & 171,692 & 29.1 \\
\hline Primary balance & 41,093 & 10.3 & 413,336 & 82.8 & 519,130 & 88.0 \\
\hline $\begin{array}{l}\text { Primary balance financed } \\
\text { by: }\end{array}$ & & & & & & \\
\hline $\begin{array}{l}\text { Capital Receipts from } \\
\text { Petroleum Fund }\end{array}$ & 40,000 & 10.1 & 396,000 & 79.4 & 512,000 & 86.8 \\
\hline $\begin{array}{l}\text { Drawdown from cash } \\
\text { reserves }\end{array}$ & 1,093 & 0.3 & 14,232 & 2.9 & 7,130 & 1.2 \\
\hline Memo item: Non-oil GDP & 398,000 & & 499,000 & & 590,000 & \\
\hline
\end{tabular}

Source: MOF and IMF staff calculation.

1/ The non-oil GDP reflects the projected outturn for 2009.

12. Since 2002 total expenditure has increased from US\$61 million to US\$681

million in 2009-i.e., by 1016 percent. Central government domestic revenues have also grown significantly between 2007 and 2009, from 5.8 percent to 14.6 percent of non-oil GDP, and the rate of increase exceeds the non-oil GDP growth rate, however the increase in

\footnotetext{
${ }^{3}$ The ESI is a benchmark indicating the sustainable level of withdrawal from the Petroleum Fund that does not reduce the real value of TLS's total petroleum wealth in the long term. According to the Petroleum Fund Law the ESI shall be 3 percent of the Petroleum Fund estimated wealth (which for this calculation includes both its financial assets as the value of petroleum reserves in production).
} 
expenditures far exceeds both the growth rate of domestic revenues and non-oil GDP. Central government spending has increased particularly significantly in capital spending and current transfers, including cash payments to displaced persons and pensions for veterans and the elderly. In 2009 withdrawals were for the first time above ESI, which is allowed if parliament approves it as being to the long-run benefit of TLS. The initial 2010 budget was not following the same trend and did not propose an increase of expenditure; however the recent supplementary budget will increase the original budget by more than 30 percent.

\section{Transfers from the Petroleum Fund have allowed an exceptionally high level of} public sector spending, however TLS's central financial management challenge remains the execution of its annual budget. In three of the last six years the actual expenditure was more than 15 percent below the original budget. The budget allocations executed by line ministry, but also by economic category reflect the government's priorities regarding development. Although recurrent expenditure constitutes the bulk of central government expenditure-more than 98.9 percent in the transition period of 2007, 82 percent in 2008, and 72 percent in 2009 - the trend is towards a relative increase of capital expenditure (from 1.1 percent of total expenditure in 2007 to 28.4 percent in 2009). Growth in capital expenditure reflects the government's commitment to address infrastructure deficiencies and accelerate economic growth. Capital spending is projected to expand rapidly in the next few years. Nevertheless, the government still shows low performance in the execution of capital spending. As the previous PEFA already pointed out, this is mainly due to a lack of capacity in, planning, budgeting and implementation planning and execution of capital and development programs in line ministries. Difficulties with executing procurement processes also play a role.

Table 2. Government Expenditures by Economic Classification (In percent of total expenditures)

\begin{tabular}{lccc}
\hline & $\begin{array}{c}2007 \\
\text { (Actual) }\end{array}$ & $\begin{array}{c}2008 \\
\text { (Actual) }\end{array}$ & $\begin{array}{c}2009 \\
\text { (Actual) }\end{array}$ \\
\hline Salaries and Wages & 27.1 & 10.4 & 14.4 \\
Goods and Services & 57.7 & 45.8 & 35.2 \\
Minor Capital & 1.1 & 8.6 & 6.4 \\
Transfers & 13.0 & 17.4 & 15.7 \\
Capital Development & 1.1 & 17.9 & 28.4 \\
& & & $\mathbf{6 0 5 , 3 3 8}$ \\
Memo item: Total Expenditures & $\mathbf{6 4 , 3 3 6}$ & $\mathbf{4 8 3 , 8 7 3}$ &
\end{tabular}

Source: MOF and IMF staff calculation. 


\section{Legal and Institutional Framework for PFM}

14. The budget covers general government (GG) almost entirely consistent with the IMF's Government Finance Statistics (GFS) principles. ${ }^{4}$ Currently only one level of government exists in the country. Subnational governments have not yet been formally established, although government is set to take steps towards decentralization in the coming years. According to the Budget and Financial Management Law (BFML) of 2009, the State budget includes all revenues and expenditures of government departments who do not have administrative and financial autonomy, and the autonomous services and funds.

\section{TLS has a well-established and comprehensive legal framework governing its} budget system, but a state audit function is still absent. The duties and responsibilities of the executive are well defined by the Constitution, including the responsibility of the government to prepare the state plan and state budget and execute them following the approval of the parliament. The High Administrative, Tax and Audit Court (HATAC) and the parliament shall monitor the execution of the budget, but the former institution has, however, not yet been set up. At present, a commercial, external auditor is contracted by the MOF.

16. The framework for management of public finances is clear and comprehensive. The BFML covers all aspects of public financial management in government including the rules and procedures for the organization, preparation, presentation, and implementation of the budget and the accounts of the state and rules and procedure for financial management. This law is applicable to the GG, and includes standard precepts of control and approval by parliament. It is comprehensive regarding its coverage of preparation of the budget, deadline for submission to the parliament, the period within which the budget should be passed, and the contents of the budget.

\section{The Petroleum Fund was established by the Petroleum Fund Law of 2005 to} contribute to a wise and sustainable management of the petroleum resources, and to a sound fiscal policy. The roles and responsibilities regarding the Petroleum Fund are divided between the parliament, the government, and the Banking and Payment Authority (BPA), and clearly stated in the law. BPA manages the fund under close supervision of the MOF. The operational rules applied to the Petroleum Fund are clearly stated in the management agreement between the MOF and BPA. The fund has no authority to spend or borrow, and is subject to regular auditing by an independent external auditor. The management costs are accounted for in the budget document.

\footnotetext{
${ }^{4}$ See IMF Government Finance Statistics Manual (GFSM) 2001.
} 


\section{Assessment of PFM Systems, Processes, And Institutions}

\section{A. Budget Credibility}

\section{PI-1. Aggregate expenditure out-turn compared to original approved budget}

\begin{tabular}{|l|c|c|}
\hline Dimension (scoring methodology M1) & Score 2007 & Score 2010 \\
\hline $\begin{array}{l}\text { The difference between actual primary expenditure and the originally } \\
\text { budgeted primary expenditure (i.e., excluding debt service charges and } \\
\text { externally financed project expenditure). }\end{array}$ & D & D \\
\hline
\end{tabular}

18. Actual primary expenditure deviated from budget estimates with more than 15 percent in two of the three years considered (see Table 3). This qualifies for a score of D. As required by the PEFA framework, donor-funded project expenditure, which is not fully under government control, was deducted from the calculation. ${ }^{5}$

19. The deviations over the three years reviewed are due to the alternating forces of in-year increases in the budget and a low execution rate. In 2007, a new government had to address many inherited problems and within a short period of time prepared two budgets: the 2007 transition period budget $^{6}$ (that was passed only in October 2007) and the 2008 budget. This might explain the low level of execution in 2007. In 2008, the government proposed and the parliament approved a supplementary budget of US $\$ 440.6$ million which was much higher than the original budget. ${ }^{7}$ The main additional expenditure item (US $\$ 240$ million) was the establishment of the Economic Stabilization Fund which was used for emergency purchases of rice and other commodities for subsidized resale. This explains the expenditure over-run recorded for this year. However, if the revised budget were to be taken as the starting point, the final out-turn would have been 79 percent of the revised budget. In 2009, there was no supplementary budget. Actual expenditure was 11 percent below the original budget which illustrated a strong improvement in budget execution processes and expenditure management, but also, reportedly, some loosening of procurement standards.

\footnotetext{
${ }^{5}$ PEFA guidelines also require excluding the debt service payments from the calculations, however, TLS presently does not have any outstanding debt.

${ }^{6}$ In 2007 the fiscal year was changed from a July 1-June 30 calendar to a January 1-December 31 calendar.

${ }^{7}$ The final outturn was US\$262.3 million higher than the original budget as the Court of Appeal in a decision held that an amount not exceeding US\$396 million could be transferred from the Petroleum Fund.
} 


\section{Table 3. Comparison Between Original and Actual Budget Expenditure (in US\$ million)}

\begin{tabular}{lcccccc}
\hline \multicolumn{1}{c}{ Description } & \multicolumn{2}{c}{ 2007 } & \multicolumn{2}{c}{ 2008 } & \multicolumn{2}{c}{$\mathbf{2 0 0 9}$} \\
& Budget & Actual & Budget & Actual & Budget & Actual \\
\hline Recurrent Expenditure & 107.7 & 63.6 & 280.1 & 397.4 & 475.5 & 433.6 \\
Capital Expenditure & 8.7 & 0.7 & 67.6 & 86.5 & 205.4 & 171.7 \\
Total Expenditure & 116.4 & 64.3 & 347.8 & 483.9 & 680.9 & 605.3 \\
Deviation (\%) & \multicolumn{7}{c}{-44.8} & 39.1 & & -11.1 \\
\hline Source: MOF; Budget Execution & Reports of 2007, 2008, 2009 (unaudited).
\end{tabular}

\section{Comparison between 2007 and 2010}

In 2007 PEFA this indicator was scored D. Overall performance did not increase notably since then but the 2009 execution rate seems to have been a major achievement of the PFM system given also the high growth rate of expenditure. In 2010 a new, large supplementary budget is expected to result in continued deviation of original budget from actual out-turn.

\section{PI-2. Composition of expenditure out-turn compared to original approved budget}

\begin{tabular}{|l|c|c|}
\hline Dimension (scoring methodology M1) & Score 2007 & Score 2010 \\
\hline $\begin{array}{l}\text { Extent to which variance in primary expenditure composition exceeded } \\
\text { overall deviation in primary expenditure (as defined in PI-1) during the } \\
\text { last three years. }\end{array}$ & Not Assessed & A \\
\hline
\end{tabular}

20. The variance in expenditure composition exceeded the overall deviation in primary expenditure by less than 5 percent in the last three years. The score is therefore an A. While there have been substantial in-year modifications of budgeted amounts, compositional variation is minimal and generally follows the original budget. See Annex III for the calculation of variances in expenditure composition in excess of the overall deviation in primary expenditure for the years 2007-09.

\section{Comparison between 2007 and 2010}

This indicator was not assessed in 2007 due to a lack of disaggregated information by administrative units.

\section{PI-3. Aggregate revenue out-turn compared to original approved budget}

\begin{tabular}{|l|c|c|}
\hline Dimension (scoring methodology M1) & Score 2007 & Score 2010 \\
\hline $\begin{array}{l}\text { Actual domestic revenue collection compared to domestic revenue estimates } \\
\text { in the original, approved budget. }\end{array}$ & A & C \\
\hline
\end{tabular}


21. Actual domestic revenue collection was below 92 percent of budgeted domestic revenue estimates in only one of the last three years. This qualifies for a C. Comparison between budgeted and received revenue provides a general indication of the quality of the revenue forecasts. The indicator looks only at the extent of over-estimation of revenues, as overestimation is not desirable, as it leads to a budget which is not fully funded and thus not credible. ${ }^{8}$ The analysis of the deviations between received and estimated revenue is based on domestic revenue and receipts from the Petroleum Fund, excluding donor funding.

22. Revenue collection includes the transfer from the Petroleum Fund, which is the biggest revenue item in the budget, and is calculated at the start of the budget process on the basis of the ESI concept. Transfers are contingent on the government providing parliament with a report specifying the ESI amount and a certification of its calculation by an independent auditor. As the system allows a recalculation of ESI for the purpose of a supplementary budget, in 2008 the transfers from the petroleum fund were increased during the fiscal year to finance additional expenditure. In 2009, the transfer from the Fund was in the end considerably lower than planned in the budget. The latter caused this indicator to score only a $\mathrm{C}$. The score would be an A if transfers were not considered in the evaluation (but only real domestic revenues).

\section{It must be noted that the level of precision in domestic revenue estimates,} excluding Fund transfers, has improved for fiscal year 2009 - the actual execution is only 5 percent below estimates. This performance is mainly attributed to simplification of tax revenue collections ${ }^{9}$ and the introduction of new practices of projecting non-tax revenue by using recent execution data, surveys on future economic activity, and monthly discussions with the line ministries.

Comparison between 2007 and 2010

In the 2007 PEFA assessment this indicator scored an A, because actual revenue collection exceeded budget amounts in all three years.

\footnotetext{
${ }^{8}$ Significant, structural underestimation of budget revenues is also not good PFM practice.

${ }^{9}$ In 2008 the legislative basis for tax collection was reformed and simplified
} 
Table 4. Comparison Between Original and Actual Budget Revenue (in US\$ million)

\begin{tabular}{|c|c|c|c|c|c|c|}
\hline \multirow[t]{2}{*}{ Description } & \multicolumn{2}{|c|}{$\begin{array}{c}2007 \\
\text { (July 1-Dec 31) }\end{array}$} & \multicolumn{2}{|c|}{2008} & \multicolumn{2}{|c|}{2009} \\
\hline & Budget & Actual & Budget & Actual & Budget & Actual \\
\hline Tax revenues & 15.5 & 14.5 & 11.5 & 37.3 & 49.3 & 46.7 \\
\hline Non-tax revenues & 7.0 & 8.7 & 15.5 & 33.2 & 41.9 & 39.5 \\
\hline Petroleum Fund & 40.0 & 40.0 & 294.0 & 396.0 & 589 & 512.0 \\
\hline $\begin{array}{l}\text { Total Revenues } \\
\text { Domestic Revenue Actuals as } \\
\text { percent of Estimates }\end{array}$ & 62.5 & $\begin{array}{c}63.2 \\
101.2\end{array}$ & 321.0 & $\begin{array}{l}466.5 \\
145.3\end{array}$ & 680.2 & $\begin{array}{c}598.2 \\
87.9\end{array}$ \\
\hline
\end{tabular}

\section{PI-4. Stock and monitoring of expenditure payment arrears}

\begin{tabular}{|l|c|c|c|c|}
\hline Dimensions (Scoring methodology M1) & \multicolumn{2}{|l|}{ Score 2007 } & \multicolumn{2}{|l|}{ Score 2010 } \\
\hline $\begin{array}{l}\text { (i) Stock of expenditure payment arrears (as a percentage of actual total } \\
\text { expenditure for the corresponding fiscal year) and any recent change in the } \\
\text { stock. }\end{array}$ & N/A & D & A & D+ \\
\cline { 1 - 2 } (ii) Availability of data for monitoring the stock payment arrears. & D & & D & \\
\hline
\end{tabular}

\section{Anecdotal information from various counterparts, including from the} commercial external auditor and the treasury, indicates that the stock of payment arrears has generally been very low (below 2 percent of total expenditure). This means that dimension (1) of this indicator can be scored an A (although there remains some degree of uncertainty on this). The reason for a virtual absence of arrears is the generally high balance of the Consolidated Fund (CF) which has facilitated prompt payment by the treasury. The background to this is that there have, on the one hand, been large and rapidly growing contributions from the Petroleum Fund each year to the CF, on the other hand underexecution of the budget has been a problem (although important progress has been made in the past two years). The resulting positive cash balance at the end of the year has not been transferred back to the Petroleum Fund, but retained in the Consolidated Fund. At the end of 2009 the balance of the Consolidated Fund was US\$162.3 million, or roughly 23.8 percent of annual government expenditure.

25. Line ministries and agencies are not cash restrained during the year, but payment delays can be caused by administrative and other reasons. As discussed under indicator PI-16, the treasury releases the budget in full to line ministries and agencies at the start of the fiscal year, meaning that line ministries can commit and pay at any time through the centralized IFMIS, up to their appropriation limit. Delays in payment may occur at the line ministry and agency level due to the need to inspect delivery of goods and services, and for other administrative reasons. Again, anecdotal evidence suggests that these delays are not 
significant. Many vendors moreover require upfront payment before final delivery. Companies do report the need to pay "incentives" in some cases to get payments executed.

26. Arrears are not defined by financial regulation, and not recorded in the IFMIS system; no reliable data exist, nor are periodic surveys carried out. This dimension therefore needs to be scored a D. Given the scoring methodology M1, the overall score for this indicator is $\mathrm{D}^{+}$.

\section{Comparison between 2007 and 2010}

This indicator scored a D in 2007 (based on one subindicator). Progress on this indicator could be made without too much effort. Arrears need to be defined according to international good practice, for example all invoices that are outstanding longer than thirty days where there is not a dispute over the delivery of goods and services, and or capital goods, should be defined as being in arrears. The IFMIS system could easily be adapted to force line ministries to enter invoices in the system when received, or alternatively to enter the due date into the system. It is good international practice that the treasury pays a penalty interest rate on all late payments of line ministries and agencies, obviously at the expense of their budget. Timely payment of bills will avoid vendors charging implicit markups for late payment on their products and will thus save the state money in the end.

\section{B. Comprehensiveness and Transparency}

\section{PI -5. Classification of the budget}

\begin{tabular}{|l|c|c|}
\hline Dimension (Scoring methodology M1) & Score 2007 & Score 2010 \\
\hline $\begin{array}{l}\text { The classification system used for formulation, execution and reporting on } \\
\text { the central government's budget. }\end{array}$ & D & B \\
\hline
\end{tabular}

27. The chart of accounts used for budget management contains an organizational, economic, and a partial functional classification. This means that this indicator scores a B. The budget is prepared, approved, monitored and reported on according to a budget classification that for the recurrent side of the budget combines the administrative and economic classifications. The capital side of the budget includes identification of unique projects under the administrative level, followed by further economic specification. Budget and fiscal reports further present information by administrative unit and line item. The economic classification is aligned with the IMF's GFSM 1986 cash-basis economic classification. The functional classification consists only of the ten main functions of the UN $\mathrm{COFOG}^{10}$ classification. The functional classification is in practice only used for budget reporting purposes, not for budget formulation. There is nothing that prohibits it from such

\footnotetext{
${ }^{10}$ Classification of the Functions of Government.
} 
use, however. The chart of accounts also contains classifications by funding source, geographic location, and program.

28. The program classification is not well developed and not used for budget management. The program classification is fully linked to the administrative classification, and describes more the main activities of administrative units than the policy objectives of government. The program classification is not comprehensive and also lacks a logical hierarchy of programs, subprograms, and activities.

29. Donors have been invited to report to the MOF on commitments, expenditures, and disbursements by first-level spending unit and highest economic category. Despite this simple format a considerable number of donors find it difficult to comply with this request. These donors only indicate under which line ministry's mandate their activities take place. The multilateral donors in general do report according to the classification scheme requested by the MOF. Donor funding comprised some 23 percent in 2010 of the so called Combined Sources Budget, which consists of the State budget and donor funded projects.

Comparison between 2007 and 2010

In 2007, separate economic classifications were used for budget preparation and execution. Since then these classifications have been harmonized, leading to an increase of the score from a D to a B.

PI-6. Comprehensiveness of information included in the budget documents

\begin{tabular}{|l|c|c|}
\hline Dimension (scoring method M1) & 2007 Assessment & 2010 Assessment \\
\hline $\begin{array}{l}\text { Recent budget documentation fulfils 6 of the } 8^{11} \\
\text { information benchmarks. }\end{array}$ & B & A \\
\hline
\end{tabular}

30. The annual budget and supporting documents, as submitted to the legislature for scrutiny and approval, allow a complete picture of central government fiscal forecasts, budget proposals, out-turns of previous years and line ministries' objectives, programs and expected results. In addition, the budget speech by the prime minister outlines government's priorities for the respective budget year and contains the information pertaining to the overall macroeconomic framework within which the annual budget has been developed. Reforms in recent years have greatly strengthened the comprehensiveness and quality of information included in the budget documents. However, the budget documentation currently does not include information on financial assets, and there is no financial statements informing on assets and liabilities of the GG. Also, no explanation of budget implications of new policy initiatives or estimates of the budgetary impact of major revenue policy changes and/or changes to expenditure programs is presented in the budget. It

\footnotetext{
${ }^{11}$ TLS does not have debt, and thus the criteria on debt stock cannot be assessed. For fair scoring the total number of criteria has been reduced to 8 with a prorate calculation.
} 
would also be important to include more explanatory materials in the budget in future, as this would help the understanding and policy-oriented discussions of budgetary issues in parliament.

Table 5. Comprehensiveness of Budget Documentation

\begin{tabular}{|c|c|c|c|}
\hline No. & Item & Included & Source \\
\hline 1 & $\begin{array}{l}\text { Macroeconomic assumptions, including at least } \\
\text { estimates of aggregate growth, inflation, and } \\
\text { exchange rate }\end{array}$ & Yes & $\begin{array}{l}\text { In Book } 1 \text { of General Budget of } \\
\text { the State and State Plan for } \\
2010 .\end{array}$ \\
\hline 2 & $\begin{array}{l}\text { Fiscal deficit, defined according to GFS, or other } \\
\text { internationally recognized standard }\end{array}$ & Yes & $\begin{array}{l}\text { In Book } 1 \text { of General Budget of } \\
\text { the State and State Plan for } \\
2010 .\end{array}$ \\
\hline 3 & Deficit financing, describing anticipated composition & Yes & $\begin{array}{l}\text { In Book } 1 \text { of General Budget of } \\
\text { the State and State Plan for } \\
2010 .\end{array}$ \\
\hline 4 & $\begin{array}{l}\text { Debt stock, including details at least for the } \\
\text { beginning of the current year }\end{array}$ & N/A & $\begin{array}{l}\text { There is no public debt, but the } \\
\text { legal provision for public } \\
\text { borrowing is clear. }\end{array}$ \\
\hline 5 & $\begin{array}{l}\text { Financial Assets, including details at least for the } \\
\text { beginning of the current year in a timely manner }\end{array}$ & No & $\begin{array}{l}\text { Information on financial assets } \\
\text { is included in the final reports. }\end{array}$ \\
\hline 6 & $\begin{array}{l}\text { Prior year's budget outturn, presented in the same } \\
\text { format as the budget proposal }\end{array}$ & Yes & $\begin{array}{l}\text { Both revenues and expenditure } \\
\text { outturns are presented in Book } \\
1 \text { of General Budget of the } \\
\text { State and State Plan for } 2010 .\end{array}$ \\
\hline 7 & $\begin{array}{l}\text { Current year's budget (either the revised budget or } \\
\text { the estimated outturn), presented in the same } \\
\text { format as the budget proposal }\end{array}$ & Yes & $\begin{array}{l}\text { Approved budget or estimated } \\
\text { outturn is included in Book } 1 \text { of } \\
\text { General Budget of the State } \\
\text { and State Plan for } 2010 .\end{array}$ \\
\hline 8 & $\begin{array}{l}\text { Summarized budget data for both revenue and } \\
\text { expenditure according to the main heads of the } \\
\text { classifications used, including data for the current } \\
\text { and previous year }\end{array}$ & Yes & $\begin{array}{l}\text { In Book } 1 \text { of General Budget of } \\
\text { the State and State Plan for } \\
2010 .\end{array}$ \\
\hline 9 & $\begin{array}{l}\text { Explanation of budget implications of new policy } \\
\text { initiatives, with estimates of the budgetary impact of } \\
\text { all major revenue policy changes and/or some major } \\
\text { changes to expenditure programs }\end{array}$ & No & $\begin{array}{l}\text { No information is provided on } \\
\text { new policies. }\end{array}$ \\
\hline
\end{tabular}

\section{Comparison between 2007 and 2010}

The 2007 PEFA assessment scored this indicator as a B because the breadth and depth of information in the budget documentation was excellent, but the previous year's outturn data was excluded. Budget documentation is more comprehensive in 2010. 
PI-7. Extent of unreported government operations

\begin{tabular}{|l|c|c|c|c|}
\hline Dimension (scoring methodology M1) & Score 2007 & \multicolumn{2}{|c|}{ Score 2010 } \\
\hline $\begin{array}{l}\text { (i) The level of unreported extra-budgetary expenditure (other than donor } \\
\text { funded projects) which is unreported, i.e., not included in fiscal reports }\end{array}$ & A & & A & \\
\cline { 1 - 1 } $\begin{array}{l}\text { (ii) Income/expenditure information on donor funded projects which is } \\
\text { included in fiscal reports }\end{array}$ & A & & D & \\
\cline { 1 - 2 }
\end{tabular}

31. Overall, the level of unreported extrabudgetary expenditure appears to be low and does not exceed one percent of budget expenditure. This qualifies the first dimension of this indicator for A. TLS has one extrabudgetary fund - the Petroleum Fund - and a limited number of public sector entities ${ }^{12}$ that are not included in the budget. Information on revenues and expenditures of the Petroleum Fund is extensively available in the budget documents, and all transfers from the fund are identified in the fund's quarterly and annual reports that are regularly published and publicly available. Most of the other public sector entities not included in the budget are (quasi) public corporations and thus would not be considered part of central government. Only the ANP and the Lottery Service could be considered parts of central government not covered in budget documents and government financial reports. Their expenditures in 2009 were less than 1 percent of government expenditures. Also, some unreported bank accounts held by line ministries and other public entities have been discovered in recent years through a survey of commercial accounts of public entities. Transactions over these accounts have been very limited, however. Information on these accounts is presently not disclosed in government financial statements or other fiscal reports. The opening of accounts under the new BFML requires an approval of the treasury, and public entities are required to report on them regularly.

\section{Donor funded expenditure is reflected in the Combined Sources Budget ${ }^{13}$ by} recurrent and capital expenditures and line ministries, but is not evaluated or approved jointly with State budget expenditure, nor is it included in other government financial reports. This dimension needs to be scored D. The National Directorate of Aid Effectiveness (NDAE) within the MOF collects annual commitment and expenditure data from donors on approved donor financed activities for budget formulation. The vast majority of the execution of the donor funding is done through separate banking arrangements in the commercial banks, and only few projects are implemented via line ministry bank accounts in the commercial banks. The treasury receives the information on the balances of these accounts

\footnotetext{
${ }^{12}$ These entities comprise: one nonfinancial public corporation: the Autonomous Service for Drugs and Health Equipment (SAMES); one financial public corporation: Microfinance Institution (IMfTL); one public institution: National Petroleum Authority (ANP); one monetary public corporation (the central bank of TLS), The Banking and Payment Authority (BPA), and a lottery service, which responds to the Ministry of Commerce and Tourism.

${ }^{13}$ Combined Sources Budget includes funds from the State Budget and external resources (donor projects).
} 
monthly; however, these projects are neither recorded nor included in the government financial reports.

\section{Comparison between 2007 and 2010}

In 2007 the score was A because the level of unreported extra-budgetary expenditure was below 1 percent of total expenditure and complete income/expenditure information for 90 percent of donor funded projects was included in the fiscal reports, except for in-kind contributions. With hindsight, there are serious doubts that the score of A for dimension (ii) was warranted in 2007 and no evidence seems to back this assessment.

\section{PI-8. Transparency of inter-governmental fiscal relations}

This indicator was not scored as TLS has no inter-governmental fiscal relations. Currently only one level of government exists in the country. Subnational governments have not yet been established. However, there is a proposal to establish municipalities (districts) in the country.

\section{PI-9. Oversight of Aggregate Fiscal Risk from Public Sector Entities}

\begin{tabular}{|c|c|c|c|c|}
\hline Dimensions (Scoring methodology M1) & \multicolumn{2}{|c|}{ Score 2007} & \multicolumn{2}{|c|}{ Score 2010} \\
\hline (i) Extent of central government monitoring of AGAs and PEs. & A & & $\mathrm{D}$ & \\
\hline $\begin{array}{l}\text { (ii) Extent of central government monitoring of SN } \\
\text { governments' fiscal position. }\end{array}$ & N/A & $\mathrm{A}$ & $\mathrm{N} / \mathrm{A}$ & D \\
\hline
\end{tabular}

33. Several autonomous government agencies (AGAs) and one prospective public enterprise (PE) are fully included in the budget and are in fact still managed as ministerial departments of the ministry of infrastructure. Electricity of Timor-Leste (EDTL), Port Authority (APORTIL), National Authority for Aviation, Institute of Equipment Management have been established by decree law as autonomous agencies, but these decrees have not been fully implemented. Radio and Television of Timor-Leste (RTTL) is to be developed into a public corporation. For Postal Services (Correios) and the Communication Agency Authority no decree law has been issued yet; as the five entities above, they are still fully part of the ministry of infrastructure. Even if according to law and regulations these entities should be autonomous, managed by a board and issued audited reports, this is not happening in practice. These entities do therefore not fall under the scope of PI-9.

34. A few other public sector entities are in fact autonomously managed and are not reported in the budget documentation. This is the case for two public corporations: the Autonomous Service for Drugs and Health Equipment (SAMES) and the Microfinance Institution (IMfTL), and one public institution, the ANP. The ANP is classified as a selffinanced public institution and is financed by transfers from the budget and fees paid by the petroleum companies operating in the Joint Petroleum Development Area (JPDA) in accordance with the Timor Sea Treaty. The BPA, the central bank of TLS, can be classified as a monetary public corporation, is autonomous, and is also not included in the budget. 
There is also a lottery service that responds to the ministry of commerce and tourism, but is not included in the budget. Notably for a state lottery, it does not deposit its revenues in the consolidated fund of government.

\section{There is neither annual monitoring, supervision nor consolidation of overall} fiscal risks for the entities that are managed autonomously from the government and which are not included in budget documents. BPA and ANP do publish annual reports and are audited. The other entities concerned do not. A new MOF directorate was established in 2009 to monitor AGAs and PEs but it is still building up its capacity. There is no system to collect and review year-end fiscal reports from these entities and consolidate fiscal information. None of these entities except SAMES are governed by an independent board. Overall, a D score is warranted for the dimension whether adequate monitoring of AGAs and PEs takes place.

36. Currently only one level of government exists in the country. Dimension two should not be scored in the current context.

\section{Comparison between 2007 and 2010}

The A score awarded in the 2007 evaluation does not seem justified and is probably due to the fact that several ministerial departments were and still are called "autonomous agencies and public corporations" in budget documents. As discussed a considerable number of them should not be considered for the evaluation of PI-9.

\section{PI-10. Public access to key fiscal information}

\begin{tabular}{|l|c|c|}
\hline Dimension (scoring methodology M1) & Score 2007 & Score 2010 \\
\hline Recent budget documentation fulfils 4 of the 6 information benchmarks. & C & B \\
\hline
\end{tabular}

37. Budget documents are available to the public, but dissemination and access could be improved. MOF publishes the draft budget documents on its website directly after the submission to the parliament; the approved budget is usually published within a couple of months after approval. Hard copies of approved budget are also available for sale to the public. However, printing all three volumes of budget documentation occurs with considerable delay and making printed versions available so late may have a limited utility to the public. Usefulness of the available materials to the general public is also questionable as the information on the website is in Portuguese and English, while the majority of the population does not have access to the internet nor speaks English or Portuguese. Moreover, the budget documents are quite technical and very detailed, and there is no summary guide to the budget in a simple language to facilitate understanding the budget. Public hearings take place very rarely, and parliamentary sessions are not open to the public. Also, the budget is not broadly discussed in the media. Some NGOs do try to disseminate budgetary information in the local language. 
38. In-year budget execution reports and year-end financial statements are made available to the public within one month of their completion. Quarterly reports on budget execution have to be presented to the parliament two months after the end of each quarter, the fourth quarterly report, which functions as preliminary end-of-year budget execution report, within three months, and audited financial statements within eight months after the end of the year. As of 2010 this last limit has been widened to nine months. All reports are published on the MOF's website after the submission to the parliament.

39. External audit reports are available to the public within six months of the completed audit on the webpage of the MOF. A state audit institution reporting to parliament has not been set up yet, but the MOF has outsourced this function to a commercial external auditor who performs a financial audit of annual financial statements and accounts. The 2008 audit report was presented to parliament in a timely manner, but management letters are kept within the executive. Management letters used to be published as well, but the letters from the last couple of years have not been published on the MOF's website.

40. Information on contract awards over US\$100 thousand is not systematically published. Only some line ministries publish tender awards in the local newspaper or on publication boards in their offices. The legal framework for procurement requires all tender awards above US $\$ 250$ thousand to be published, and from 2010 onwards the procurement unit in the vice prime minister's office intends to publish all tender awards in the local newspaper and on the website of the MOF.

\section{Information on resources from the state budget allocated to primary units such as schools and clinics is not published in the budget documents.}

\section{Comparison between 2007 and 2010}

The 2007 PEFA assessment scored this indicator as a $\mathrm{C}$ because the budget documentation was available after adoption, but other information was not. The change of score seems to adequately reflect an improvement in performance. 
Table 6. Access to Fiscal Information

\begin{tabular}{|c|c|c|c|}
\hline No. & Item & Included & Source \\
\hline 1 & $\begin{array}{l}\text { Annual Budget } \\
\text { Documentation }\end{array}$ & Yes & $\begin{array}{l}\text { All draft budget documents are published on the } \\
\text { website of the MOF directly after the submission to } \\
\text { the parliament; the approved budget is published a } \\
\text { couple of months after the approval by the } \\
\text { legislature: www.mof.gov.tl. }\end{array}$ \\
\hline 2 & In-year execution reports & Yes & $\begin{array}{l}\text { All reports are available to the public after the } \\
\text { presentation to the parliament on the website of the } \\
\text { MOF within one month of their completion: } \\
\text { www.mof.gov.tl }\end{array}$ \\
\hline 3 & $\begin{array}{l}\text { Year-end financial } \\
\text { statements } 6 \text { months } \\
\text { after end of fiscal year }\end{array}$ & Yes & $\begin{array}{l}\text { The annual budget execution report is available to } \\
\text { the public after the presentation to the parliament } \\
\text { on the website of the MOF within one month of its } \\
\text { completion: www.mof.gov.tI }\end{array}$ \\
\hline 4 & External audit reports & Yes & $\begin{array}{l}\text { The audited final accounts are made available to } \\
\text { the public in a timely manner. }\end{array}$ \\
\hline 5 & Contract awards & No & $\begin{array}{l}\text { Information on tender awards is not published } \\
\text { systematically. }\end{array}$ \\
\hline 6 & $\begin{array}{l}\text { Resources available to } \\
\text { primary service units }\end{array}$ & No & $\begin{array}{l}\text { Information on resources received by primary } \\
\text { service providers is not available. }\end{array}$ \\
\hline
\end{tabular}

\section{Policy-based Budgeting}

PI-11. Orderliness and participation in the annual budget process

\begin{tabular}{|c|c|c|c|c|}
\hline Dimension (scoring methodology M2) & \multicolumn{2}{|c|}{ Score 2007} & \multicolumn{2}{|c|}{ Score 2010} \\
\hline (i) Existence and adherence to a fixed budget calendar. & $\mathrm{B}$ & \multirow{3}{*}{ B } & ( & \multirow{3}{*}{$\mathrm{C}+$} \\
\hline (ii) Guidance on the preparation of budget submissions. & A & & ( & \\
\hline (iii) Timely budget approval by the legislature. & $\mathrm{C}$ & & $\overline{\mathrm{F}}$ & \\
\hline
\end{tabular}

\section{A clear annual budget calendar exists and is generally complied with, however} some delays are experienced in its implementation and it does not allow line ministries a reasonable amount of time to complete their capital budget submissions. This means that dimension one of this indicator qualifies for a C. Budget preparation commences in January of the year preceding the fiscal year with the issuance of budget timetable that covers all activities undertaken in the budget, treasury and procurement area, and culminates in the adoption of the budget law by parliament at the end of the year. Only the due date for submission of the draft budget to the parliament is fixed in the BFML (October 15). Other specific dates and formats for each phase of the budget preparation are set in the budget circular usually issued by the MOF in May. The calendar allows two weeks for line ministries to complete their detailed estimates of capital expenditure and four weeks for recurrent expenditure. The time envisaged for formulating the capital budget is insufficient to 
complete meaningful estimates on time, and in practice either the deadline has not been fully followed or very incomplete investment projects are submitted.

43. The budget procedures are guided by the budget circular that prescribes ceilings for the recurrent budget for the fiscal year; however no ceilings are included for the capital budget. This dimension scores a $\mathrm{C}$. The budget circular is comprehensive and for the most part can be described as clear and useful, however no relevant macroeconomic information is passed on to line ministries and there are no explicit budget ceilings for capital budget at the outset of the budget preparation process, only indication of the expected aggregate capital budget envelope. The budget circular does establish clear ceilings for the recurrent budget of line ministries and their main economic categories of spending. These are approved by the COM prior to their distribution to line ministries. The quality of the recurrent budget envelopes is not that good, as in practice the ceilings for line ministries are drawn up on the basis of extrapolation of historic figures. They do not take into account the cost drivers of line ministry budgets. The submissions are generally considerably above the provided envelopes. Moreover, line ministries do not always provide all the information requested in the circular. During the consolidation process of budget submission, there is little interaction between the MOF and line ministries. MOF review capacity is very weak, both on the recurrent and capital side.

44. During two of the last three years the legislature has approved the budget before the start of the fiscal year. This qualifies dimension three for the score of B. The 2007 and 2008 budgets were approved on time; however, the 2009 budget was approved in the beginning of the fiscal year (in February 2009).

\section{Comparison between 2007 and 2010}

In 2007 this indicator scored a B, while the overall score in 2010 is $\mathrm{C}+$. There is some evidence that the budget process was somewhat more orderly, with more time provided to line ministries, while more comprehensive expenditure ceilings were issued for budget preparation.

PI-12. Multiyear perspective in fiscal planning, expenditure policy and budgeting

\begin{tabular}{|l|c|c|c|c|}
\hline Dimension (scoring method M2) & \multicolumn{2}{|c|}{ Score 2007 } & \multicolumn{2}{|c|}{ Score 2010 } \\
\hline (i) Multiyear fiscal forecasts and functional allocations. & $\mathrm{A}$ & & $\mathrm{C}$ & \\
\cline { 1 - 2 } (ii) Scope and frequency of debt sustainability analysis. & $\mathrm{A}$ & $\mathrm{N} / \mathrm{A}$ & \\
\hline (iii) Existence of cost sector strategies. & $\mathrm{A}$ & $\mathrm{C}$ & $\mathrm{D}+$ \\
\cline { 1 - 2 } $\begin{array}{l}\text { (iv) Linkages between investment budgets and forward expenditure } \\
\text { estimates. }\end{array}$ & $\mathrm{C}$ & & $\mathrm{D}$ & \\
\hline
\end{tabular}

45. To date, a multiyear perspective on fiscal planning is at an initial stage of development in TLS. There is no top-down, multiyear estimation of fiscal aggregates. The BFML calls for the budget to be entered with a multiyear perspective. The budget document presents a four-year (budget year plus three years) bottom-up forecast of revenues and 
expenditures, and of the resulting deficit and its financing, however revenue and expenditure forecasts are obtained by an incremental approach and lack the support of robust estimations about the future evolution of the main macroeconomic variables or fully costed expenditure proposals. Links between multiyear estimates and subsequent setting of annual budget ceilings are unclear and differences not explained. This qualifies the dimension one for the score C.

46. Currently there is no public debt in TLS, and therefore no debt sustainability analysis needs to be undertaken. This means dimension two cannot be scored.

47. Some sectors (such as health and education) have prepared broadly costed sector strategies. However, these strategies are not integrated into the government priorities or SDP, and their costing is not developed within resource envelopes derived from mediumterm forecasts. The annual budget is accompanied by the annual action plans (AAPs) of the line ministries which outline the objectives, programs, and results. However, the plans contain no link to the budget allocations. This means that the dimension three can be scored a C.

48. TLS has a dual budget process where the capital and recurrent budgets are developed separately, with no calculation of the recurrent cost of public investment. The recurrent and capital budgets are only linked in as much as they are reported together in the same budget document. While the recurrent budget is to a large extent finalized by the MOF, capital projects are selected and prioritized under the supervision of the prime minister. No specific attention is paid to reconciling the budgets to ensure that for all development projects included in the budget, corresponding recurrent costs are considered for both the budget year and for future years. The budget circular requires detailed information for recurrent and capital expenditure, however, the line ministries do not always adhere to this. Also, there is no formal analytical framework in place to assess the overall implications of capital projects.

\section{Comparison between 2007 and 2010}

In 2007 this indicator was scored B+. The linkage between multi-year estimates and setting of budget ceilings seems to have been over-estimated. Sector investment programs were used as a basis for budget preparation, however, it was unclear to what extent these programs were fully costed for both capital and recurrent expenditure and their linkage to forwards estimates. They are not developed anymore, so there does seem to be some slippage in the sophistication of budget preparation. 


\section{Predictability and Control in Budget Execution}

PI-13 Transparency of taxpayer obligations and liabilities

\begin{tabular}{|c|c|c|c|c|}
\hline Dimensions (Scoring methodology M2) & Scor & 07 & Sco & \\
\hline (i) Clarity and comprehensiveness of tax liabilities. & $\mathrm{C}$ & \multirow{3}{*}{$\mathrm{D}+$} & $\mathrm{C}$ & \multirow{3}{*}{$\mathrm{C}$} \\
\hline $\begin{array}{l}\text { (ii) Taxpayers' access to information on tax liabilities and administrative } \\
\text { procedures. }\end{array}$ & $\mathrm{D}$ & & $\mathrm{C}$ & \\
\hline (iii) Existence and functioning of a tax appeals mechanism. & $\mathrm{D}$ & & $\mathrm{C}$ & \\
\hline
\end{tabular}

49. While determination of tax liabilities is reasonably clear, revenue collection procedures are still complex and allow for discretionary powers of customs officers. Self-assessment is a major feature of the Timorese tax system. In the petroleum sector, complex tax legislation makes it difficult for citizens and the tax administration to understand the companies' obligations, entitlements, and rights. For domestic tax and customs, the legislative basis for tax rates and duties was recently reformed with the Taxes and Duties Act of 2008, but this modernization process has not yet covered revenue administration where old United Nations Transitional Administration of East Timor (UNTAET) regulations still apply. This administrative complexity gives tax and customs officers a fair amount of discretionary powers, which does not exceed, however, what is foreseen by legislation and regulations for Domestic and Petroleum tax, but which in practice is still a major concern in the customs area. Customs is in the process of increasing accountability through documentation of work plans, monitoring of procedures, and training. The dimension on clarity and comprehensiveness of tax liabilities is scored a $\mathrm{C}$.

50. Except for customs, most of the revenue legislation is available on the MOF website. Dissemination campaigns are conducted through the media and targeted campaigns. Recently, tax information brochures have been posted on the MOF website in four languages (English, Tetum, Portuguese, and Indonesian). There is nevertheless a critical difference between the Portuguese and English versions of many laws and regulations.

51. The tax legislation that applies to petroleum companies and service companies is available on the website of the Petroleum Revenue Directorate. The Directorate advises tax payers on their tax liability on a monthly basis. Other information about tax rules or decisions is not published by the Directorate, but a FAQ for the website is currently under preparation. The companies liable to the special petroleum taxation are mainly international companies with experience in operating under different fiscal regimes, and there have been no complaints on the complexity of the tax legislation.

52. The Tax and Duties Act of 2008 does not deal with the legal regime applicable for the collection and recovery of tax. The UNTAET regulations provide a basic legal framework, but in its current form, it does not meet international standards or the needs of a modern revenue administration. It means that while taxpayers have some access to 
information on tax liabilities, access to information on administrative procedures is much more difficult since this information is far from being comprehensive and user-friendly. A new draft decree law on collection and recovery is being prepared. The score on taxpayer access to information on tax liabilities and administrative procedures is scored a $\mathrm{C}$.

53. An administrative procedure for tax appeals is in place but is not efficient and independent enough. UNTAET Regulation No. 2000/18 establishes a comprehensive tax appeals mechanism comprising an administrative complaint procedure, a Board of Tax and Customs appeals, and the HATAC for cases which were not solved by the Board. The Board and the High Court have not yet been set up. Moreover, the administrative appeal, involving the Appeals Division of the tax administration, does not seem to function properly for lack of capacity and because the process is reportedly hampered by issues of corruption. Taxpayers willing to contest decisions and assessments made by the tax administration often need to make use of personal relationships or political intervention. The lack of a comprehensive and efficient tax appeals mechanism for petroleum taxes also raises complaints from petroleum companies subject to Timorese tax laws. The score is $\mathrm{C}$ for this dimension. The overall score of the indicator is $\mathrm{C}$.

\section{Comparison of 2007 and 2010}

Performance has progressed since 2007 in terms of taxpayer's access to information lifting the score from $\mathrm{D}+$ to $\mathrm{C}$.

PI-14 Effectiveness of measures for taxpayer registration and tax assessment

\begin{tabular}{|l|c|c|l|}
\hline Dimensions (Scoring methodology M2) & \multicolumn{2}{|c|}{ Score 2007 } & \multirow{2}{*}{ Score 2010 } \\
\hline (i) Controls in the taxpayer registration system. & C & C \\
\cline { 1 - 2 } $\begin{array}{l}\text { (ii) Effectiveness of penalties for non-compliance with registration } \\
\text { and declaration obligations. }\end{array}$ & B C & C & D+ \\
\cline { 1 - 3 } $\begin{array}{l}\text { (iii) Planning and monitoring of tax audit and fraud investigation } \\
\text { programs. }\end{array}$ & C & D \\
\hline
\end{tabular}

54. Controls in the taxpayer registration system are improving but still need to be strengthened. Initial reforms such as a unique Taxpayer Identification Number have been introduced (TIN). It is shared within revenue administration and is fairly efficient. Its accuracy and completeness benefit from third party checks and occasional surveys. However, the TIN is not yet linked with other databases, such as for business registration. The score for the first dimension is $\mathrm{C}$.

\section{A system of penalties for non-compliance with registration and tax declaration} exists but is not very effective. In TLS, tax payment and tax declaration happen at the same time. A penalty applies for late lodging of a tax return: US\$100 plus 5 percent after one month plus 1 percent more every month. These penalties are not sufficiently well administered and followed-through to have the desired impact. Compliance in payment of 
domestic taxes is very low. A substantial change in penalty administration and judicial follow-through seems necessary. For the petroleum sector on the other hand some tax penalties do not seem sufficiently high to have an impact on behavior. However, tax compliance in the petroleum sector, at least with regard to tax declaration, is very high. For customs the penalty regime is of less importance. The score of this second dimension is $\mathrm{C}$.

56. Tax audits and fraud investigations are conducted on a limited basis. Although basic audit checklists, technical reference manuals, and other material are maintained on the shared directory of the revenue administration information network, there is insufficient tax, administrative, and audit expertise within the MOF General Directorate of Revenue and Customs (GDRC) to provide an appropriate audit service. There is no comprehensive and documented audit plan and audits are conducted only to a limited extent according to clear risk criteria. Sector-based audit plans for small and large businesses have been developed, but these are in fact not operational. The GDRC plans to strengthen its audit unit in each of the three National Directorates (Petroleum Revenue, Customs, and Domestic Tax).

\section{The Petroleum Tax Directorate is responsible for conducting tax audits on} companies in the petroleum sector. However, since 2007 this has not been possible due to a dispute over sovereignty rights with Australia making it impossible for the directorate to carry out audits on Australian soil, despite agreement with the petroleum companies themselves. The Directorate does seem to have adequate powers to oblige companies to provide records in TLS if necessary, but this is seen as impractical as access to accounting systems and personnel is also sought during audits. The transactions in the Production Sharing Contracts in the JPDA, jointly administered with Australia, are however audited on a regular basis, and this gives some reassurance for the assessment of costs incurred in these licenses. The score for this dimension is $\mathrm{D}$. The overall score of this indicator is $\mathrm{D}+$.

\section{Comparison of 2007 and 2010}

The score is lower in 2010, D+ against C+ in 2007 is caused mainly by the lower performance of tax audits. The score for the effectiveness of the penalty regime also decreased. Tax audits seem to be at present a major weakness in the tax administration system.

\section{PI-15 Effectiveness in collection of tax payments}

\begin{tabular}{|c|c|c|c|c|}
\hline Dimensions (Scoring methodology M1) & Sco & 2007 & & 010 \\
\hline $\begin{array}{l}\text { (i) Collection ratio for gross tax arrears, being the percentage of tax arrears at } \\
\text { the beginning of a fiscal year, which was collected during that fiscal year } \\
\text { (average of the last two fiscal years), and/or significance of total amount of } \\
\text { tax arrears. }\end{array}$ & $\mathrm{D}$ & \multirow{3}{*}{$\mathrm{D}+$} & A & \multirow{3}{*}{$\mathrm{D}^{+}$} \\
\hline $\begin{array}{l}\text { (ii) Effectiveness of transfer of tax collections to the treasury by the revenue } \\
\text { administration. }\end{array}$ & A & & A & \\
\hline $\begin{array}{l}\text { (iii) Frequency of complete accounts reconciliation between tax assessments, } \\
\text { collections, arrears records and receipts by the treasury. }\end{array}$ & $\mathrm{D}$ & & $\mathrm{D}$ & \\
\hline
\end{tabular}


58. The necessary data for calculating the collection ratio for tax arrears is not produced routinely. Information provided by the system for management of domestic taxes, SIGTAS, shows that the total amount of tax arrears remains insignificant (less than 1 percent of annual total revenue collection, i.e., around US\$3 million, of which US\$800,000 are considered uncollectible). These arrears are all in the area of domestic taxes. Taken separately, without including petroleum taxation in overall revenue collection, where there are no arrears, the level is quite high. The score of dimension one is A.

59. Revenue collections are transferred to the treasury's main account daily.

Domestic tax and customs revenues are swept daily from the commercial banks to the TSA. ${ }^{14}$ Petroleum revenues are paid into the BPA on a monthly basis by petroleum companies. The score is A.

60. Complete reconciliation on tax assessments, collections, arrears, and transfers to (and receipts by) the treasury is done manually every month with up to six weeks delays for the Domestic and Petroleum Tax Directorates. Customs conducts monthly reconciliation with up to four months delay. Since customs represents more than a third of all domestic revenue collections, the score for this dimension is a $\mathrm{D}$ (it would be a B if only Domestic and Petroleum tax were considered).

Comparison between 2007 and 2010

The overall score remains D+. ${ }^{15}$ The improvement in dimension one between 2007 and 2010 is due to the fact that all taxes were considered for calculating the arrears ratio.

PI-16. Predictability in the Availability of Funds for Commitment of Expenditure

\begin{tabular}{|c|c|c|c|c|}
\hline Dimensions (Scoring methodology M1) & Sc & 009 & Sc & \\
\hline (i) Extent to which cash flows are forecast and monitored. & $\mathrm{D}$ & \multirow{3}{*}{$\mathrm{D}+$} & B & \multirow{3}{*}{$\mathrm{B}+$} \\
\hline $\begin{array}{l}\text { (ii) Reliability and horizon of periodic in-year information to MDAs on } \\
\text { ceilings for expenditure commitments. }\end{array}$ & $\mathrm{C}$ & & A & \\
\hline $\begin{array}{l}\text { (iii) Frequency and transparency of adjustments to budget allocations, } \\
\text { which are decided above the level of management in MDAs. }\end{array}$ & $\mathrm{B}$ & & $\mathrm{B}$ & \\
\hline
\end{tabular}

61. The treasury, in consultation with the BPA, prepares a cash flow forecast for the fiscal year at the beginning of the year. It is reviewed every quarter and changes are made,

\footnotetext{
${ }^{14}$ Sweeping arrangements are in place for all three commercial banks, but all revenue transfers in fact take place through one bank at present.

15 The score in the 2007 report for this indicator was D, but the correct aggregation of dimensional scores leads to a $\mathrm{D}+$.
} 
if necessary. Changes are made generally as a consequence of an increase in the budget outlay because of a midyear supplementary budget. Since most revenue inflows are certain due to assured transfers from the Petroleum Fund, the treasury allows MDAs to commit expenditures for the entire year through the issuance of Expenditure Authorization Notices sent out early in the financial year. The government does not present more than one supplementary budget in a year. In the fiscal year 2009 the government did not present a supplementary budget but there will be one in 2010. Supplementary budgets are presented in the same basic format as the overall budget. Some have the nature almost of a second budget, which under good practice in PFM is not the intention of supplementaries.

\section{Comparison of 2007 and 2010}

The overall score of this indicator has improved from $\mathrm{D}+$ to $\mathrm{B}+$ which adequately reflects the improvement in performance.

PI-17. Recording and Management of Cash Balances, Debt, and Guarantees

\begin{tabular}{|l|l|l|l|}
\hline Dimensions (Scoring methodology M1) & \multicolumn{2}{|l|}{ Score 2007 } & \multicolumn{2}{l|}{ Score 2010 } \\
\cline { 1 - 2 } (i) Quality of debt data recording and reporting. & N/A & \multirow{2}{*}{ N/A } & \\
\cline { 1 - 2 } (ii) Extent of consolidation of government's cash balances. & A & C & N/A \\
\cline { 1 - 2 } \cline { 1 - 2 } (iii) Systems for contracting loans and issuance of guarantees. & N/A & N/A \\
\hline
\end{tabular}

62. The government of TLS had not contracted any debt until the end of the financial year 2009. Dimension one should therefore not be scored.

\section{The government operates a TSA at the BPA where cash balances are} consolidated and calculated daily. The BPA is able to provide details of cash balances each day. However, substantial government cash balances, both under treasury or line ministry control, are retained in bank accounts in commercial banks which do not form part of the consolidated cash balances of government. These accounts should be integrated into the TSA and balances retained as claims on the treasury if authority to spend of the funds has not lapsed. Activity on these accounts should be reported on in fiscal reports. This dimension is scored a C.

64. The government has not contracted loans nor has it issued guarantees of any kind till the end of the financial year 2009. Dimension three should therefore not be scored.

\section{Comparison of 2007 and 2010}

There is some evidence that the 2007 assessment underestimated the amounts kept outside MOF's management, scoring dimension two too generously. 
PI-18. Effectiveness of Payroll Controls

\begin{tabular}{|c|c|c|c|c|}
\hline Dimensions (Scoring methodology M1) & Sec & 007 & Scol & \\
\hline $\begin{array}{l}\text { (i) Degree of integration and reconciliation between personnel records and } \\
\text { payroll data. }\end{array}$ & $\mathrm{C}$ & \multirow{4}{*}{$\mathrm{D}+$} & $\mathrm{D}$ & \multirow{4}{*}{$\mathrm{D}+$} \\
\hline (ii) Timeliness of changes in personnel records and the payroll. & A & & B & \\
\hline (iii) Internal controls of changes to personnel records and the payroll. & $\mathrm{C}$ & & A & \\
\hline $\begin{array}{l}\text { (iv) Existence of payroll audits to identify control weaknesses and/or ghost } \\
\text { workers. }\end{array}$ & $\mathrm{D}$ & & $\mathrm{D}$ & \\
\hline
\end{tabular}

65. The treasury has been requesting MDAs periodically to reconcile the personnel databases, and individual personnel records, with the payroll executed by treasury. Reconciliation by MDAs, however, had not been done until the end of the financial year 2009, except by three ministries. Personnel records are, reportedly, not complete in many ministries. The treasury makes changes to its payroll database only on the basis of inputs received from MDAs or the Public Service Commission. Because personnel records and payroll database are not reconciled in any systematic way, dimension one scores a D.

66. There is anecdotal evidence that occasionally, changes in the payroll due to transfers, promotions, and hiring of temporary staff, are made with a delay of up to three months. Dimension two scores a B.

\section{Authority to change records and payroll is restricted and subject to internal} controls. While controls may not be fully in place in line ministries, all changes to the nominal roll are reviewed by the Public Service Commission. In treasury, the IFMIS system has its own sets of control and error correction mechanisms. All changes in the payroll are now effected by the director of the treasury on the advice of the Public Service Commission. An A is warranted for dimension three.

68. No audit of payroll has taken place for many years. The PEFA report of 2007 indicates that an audit of the payroll was last undertaken by the Inspector General's Office in 2001/02 in the districts. The external auditor appointed by the government to audit the annual financial statements of government has only conducted a test audit of the payroll in a few ministries. The Public Service Commission which was appointed last year is in the process of reconstructing and updating personnel records of all employees in the government of TLS.

Dimension four scores a D.

\section{Comparison between 2007 and 2010}

The overall score remains a D+. This hides, though, that there have been major improvements in the payroll process within treasury and through the Public Service Commission. 
PI-19. Competition, value for money and controls in procurement

\begin{tabular}{|c|c|c|c|c|}
\hline Dimension (scoring method M2) & & 2007 & & \\
\hline $\begin{array}{l}\text { (i) Use of open competition for award of contracts that exceed the } \\
\text { nationally established monetary threshold for small purchases. }\end{array}$ & $\mathrm{D}$ & \multirow{3}{*}{ B } & $\mathrm{D}$ & \multirow{3}{*}{$\mathrm{C}$} \\
\hline (ii) Justification for use of less competitive procurement methods. & A & & $\mathrm{C}$ & \\
\hline (iii) Existence and operation of a procurement complaints mechanism. & $\mathrm{B}$ & & B & \\
\hline
\end{tabular}

69. While the legal framework for procurement recommends the use of competitive bidding processes, there is much leeway in practice for use of less competitive methods. The legal framework identifies the following procurement methods: competitive bidding, prequalification followed by a limited tender, restricted tender by direct invitation, tender by negotiation, request for quotation, direct appointment, and simplified procedure. The latest set of legal amendments introduced in the context of fiscal decentralization provides for a further exception by requiring construction works up to US\$250 thousand to be executed by district level companies using special procedures. This is intended to promote local development. The process requires selection of qualified companies to execute the works. However, there is no requirement for competition or comparison of proposals.

70. The current legal framework has too many procurement procedures and several of these allow for non-competitive processes. Additionally, several other procedures contribute to decreasing the efficiency of competition such as requiring restriction of award to national bidders in case of contracts less than US\$100 thousand; awards to firms at district level with no competition, not having separate procedures for selection of consultants; a complicated evaluation process based on use of two envelops and quality evaluation even for simple works/goods. Additionally, there is possibility for some agencies to have their own procedures.

71. The institutional responsibilities for procurement has been in a state of flux for a number of years, with decentralization, centralization, and most recently again decentralization following each other. In 2006-07 procurement was nearly dysfunctional due to a legalistic and complex framework not aligned with line ministry capacities. In 2008 MOF centralized procurement to ensure adequate capital budget execution. Since then a process of decentralization has been started, with capacity building and accreditation of procurement departments in line ministries. The most recent change occurred early 2010 with the full delegation of procurement responsibility to all ministries of all contracts up to US\$1 million. Contracts estimated to cost more than one million dollars will no longer be supervised/administrated by MOF but by the vice prime minister's office (on behalf of the prime minister) while awards for contracts above US\$3 million will be approved by the Council of Ministers (COM). In the vice prime minister's office a procurement technical secretariat is being set up to carry out the tasks associated with the new procurement responsibilities, as well as a procurement monitoring commission for verifying and 
monitoring implementation of procurement. The Directorate of Procurement at MOF is still assumed to carry out its previous functions of policy formulation, regulation, capacity building, and data management. There are significant coordination, resource and capacity issues that arise from this new reorganization. Most importantly, many ministries are still struggling to carry out their newly delegated procurement functions.

72. Despite this turbulent environment, competitive bidding, either domestic or international, reportedly takes place in the majority of cases; however there is no functioning monitoring mechanism at the center of government to track the relative use of competitive bidding. Counterparts in various ministries indicated that competitive bidding is still the most prevalent form of contracting, though exceptions are becoming more and more prevalent. Line ministries have, however, neglected their reporting requirements to the MOF Procurement Directorate, and new arrangements still have to be made with the vice prime minister's office. Government-wide monitoring reports are not being prepared. For this reason the first dimension, measuring data on the prevalence of open competition, needs to be scored a D.

\section{The justification for the use of less competitive methods is not always strongly} argued, and legislation and decrees have tended to increase the scope for noncompetitive methods on an ad hoc basis. The justification for using non-competitive methods is prescribed in law and provided by the relevant authority in particular cases. There is little hard evidence on the appropriate or inappropriate use of exceptions, but based on interviews with counterparts the argumentation is often said to be weak. Moreover on more than one occasion decrees have designated exceptions for large packages of procurement contracts on an ad hoc basis. ${ }^{16}$ For this reason the second dimension, measuring the extent of justification for less competitive procurement, is scored a C.

\section{An administrative process, defined by law, exists for submitting and addressing} procurement complaints, which is accessible and provides for timely resolution of complaints. Articles 96 to 102 of decree law 10/2005 sets out the procedures for handling complaints. Bidders can address their complaints to the procurement service unit conducting the process during bidding or within five days from announcing the decision to award. The articles set limits for the procurement service unit to take actions on accepting the complaint, assessing its validity, possible suspension of the procurement process and final decision on

\footnotetext{
${ }^{16}$ For example, the 2008 large, emergency supplementary budget in response to the global crisis included an allocation of US\$240 million for the purchase of rice and other commodities. Bypassing of normal procurement processes was allowed by decree. In 2009 the government allocated US\$60 million from the Electricity Project for the Referendum Package which was for undertaking development works in districts using national contractors only. The funds were released, using simplified payment procedures, to the bank account of AECOOP, which represents the interests of local business for transfer to the accounts of contractors who were entrusted with task of carrying out development works in districts.
} 
the complaint. Within a period of five days of the final decision of the procurement services unit, the complainant has the right to appeal such decision to a higher authority. This authority can be the direct managers of the procurement service unit or minister/heads of autonomous agency as the case may be. Appeal can also be submitted to the prime minister in cases concerning ministers or heads of autonomous agencies. The decree requires written documentation on each complaint and decisions made.

75. While a formal process exists, the obvious weakness is that there is no external, independent oversight body over the complaints process. Also the fact that the initial complaint is lodged to the procurement service, and in practice the procurement committee itself implementing the tender, does not give adequate checks and balances for a fair and unbiased review. There is also no process information on the number of complaints received and how they were resolved. These supervision tasks are to be fulfilled by the new procurement monitoring commission. However, there is an administrative process defined by law, it is used by participants on a regular basis, and it does lead to timely, administrative resolution of the complaints issued. For this reason the third dimension, on the existence and operation of a complaints mechanism is scored a B. The overall indicator is assessed as $\mathrm{C}$.

\section{Comparison between 2007 and 2010}

In 2007 the score given was D+ but should have been B according to scoring methodology

M2. It seems that dimension two may have been scored on the basis of the legal and regulatory framework instead of the actual practices.

\section{PI-20. Effectiveness of Internal Controls for Non-Salary Expenditure}

\begin{tabular}{|l|l|l|l|l|}
\hline Dimensions (Scoring methodology M1) & \multicolumn{2}{|c|}{ Score 2009 } & \multicolumn{2}{|c|}{ Score 2010 } \\
\hline (i) Effectiveness of expenditure commitment controls. & C & & A & \\
\cline { 1 - 2 } $\begin{array}{l}\text { (ii) Comprehensiveness, relevance and understanding of other internal } \\
\text { control rules/procedures. }\end{array}$ & D & D+ & C & C + \\
\cline { 1 - 2 } $\begin{array}{l}\text { (iii) Degree of compliance with rules for processing and recording } \\
\text { transactions. }\end{array}$ & B & B \\
\hline
\end{tabular}

76. Rules and procedures for effecting payment are generally followed strictly in the treasury. Under normal circumstances no commitments can be entered in FreeBalance system by line ministries unless adequate appropriation for the purpose exists. Instances of release of funds using emergency procedures for specific purposes involving significant amount of funds, especially in 2009, have been observed. Nevertheless, adequate controls exist in the treasury system to ensure that even in the case of emergency situations payment is not effected unless approvals from the authority competent to do so are obtained. Dimension one is scored an A.

77. Staff in the MDAs is still not very conversant with rules and procedures for internal control. Moreover, financial regulations need updating with respect to internal 
controls, staff in MDAs needs to be trained and capacity enhanced. There seems to be a tendency to rely extensively on the IFMIS system to provide controls for the expenditure process, especially at the commitment level. Dimension two scores a C.

78. Despite training on use of the IFMIS system by line ministries for data entry, quite a few errors are still made; emergency or simplified procedures are not often used. Staff in the treasury continues to spend a considerable amount of time correcting Commitment and Payment Vouchers (CPVs) from MDAs and in requesting their staff to attach the correct documentation needed for processing CPVs. This dimension is scored a B.

\section{Comparison between 2007 and 2010}

The increase in the overall score from $\mathrm{D}+$ to $\mathrm{C}+$ can be explained by the successful development of the IFMIS system in the MOF over the past few years.

\section{PI-21. Effectiveness of Internal Audit}

\begin{tabular}{|c|c|c|c|c|}
\hline Dimensions (Scoring methodology M1) & Sec & 2007 & Sec & 010 \\
\hline (i) Coverage and quality of the internal audit function. & $\mathrm{D}$ & \multirow{3}{*}{$\mathrm{D}$} & $\mathrm{D}$ & \multirow{3}{*}{$\mathrm{D}$} \\
\hline (ii) Frequency and distribution of reports. & $\mathrm{D}$ & & $\mathrm{D}$ & \\
\hline (iii) Extent of management response to internal audit findings. & $\mathrm{D}$ & & $\mathrm{D}$ & \\
\hline
\end{tabular}

79. The internal audit department in the MOF consists of only four staff, and is just starting to deploy activities. The Department has been hampered by capacity issues and has not been able to undertake meaningful audits until recently. All the personnel in the department were sent abroad for a short term specialized training in an effort to improve capacities in the department. An annual audit plan has not been prepared so far. Internal audit units exist in some line ministries, but even when set up, are generally only engaged in simple inspection activities not in systemic audits. Reporting by internal audit units is very irregular and usually case-specific. There are no annual internal audit reports of MDAs and reports are generally not sent to the MOF. The follow-up on internal audit recommendations seems minimal.

\section{The Inspector General Office (IGO) was created in $\mathbf{2 0 0 0}$ during the UN interim} government as the internal auditor for the whole of government. In 2009 its responsibilities were expanded by the Decree-Law No. 22/2009. This legislation which provides a mandate of four years for the Inspector General, enables the IGO to undertake inspections and audit in all public entities. It also provides that all Public Enterprises give the IGO full access of documents and information necessary to conduct its activities. The Inspector General reports to the prime minister. An annual audit plan has thus far not been prepared. The staff is limited and capacity is weak. Incidental reports are prepared on investigated issues, but there is no IGO annual report. The internal audit units in ministries 
respond technically to but are not subordinate to the IGO. All dimensions on internal audit are scored $\mathrm{D}$ resulting in an overall score of $\mathrm{D}$.

Comparison between 2007 and 2010

Scores and performance are identical in both assessments.

\section{E. Accounting, Recording, and Reporting}

\section{PI-22. Timeliness and Regularity of Accounts Reconciliation}

\begin{tabular}{|l|c|c|c|c|}
\hline Dimensions (Scoring methodology M2) & \multicolumn{2}{|l|}{ Score 2009 } & \multicolumn{2}{l|}{ Score 2010 } \\
\hline (i) Regularity of bank reconciliations. & D & & B & \\
\cline { 1 - 2 } \cline { 1 - 2 } $\begin{array}{l}\text { (ii) Regularity of reconciliation and clearance of suspense } \\
\text { accounts and advances. }\end{array}$ & D & & B & \\
\hline
\end{tabular}

81. Bank reconciliations for the TSA held at the BPA take place within two weeks of the close of every month. Bank reconciliations which were in arrears from the financial year 2005 were brought up to date during 2009 and since then the process has been formalized. However, reconciliation of government accounts held in commercial banks does not take place. The government financial regulations do not have any provision for operation of suspense or other accounts held by line ministries. In total there are some 197 commercial bank accounts held by line ministries and agencies with holding of US\$72 million. Dimension one is scored a B.

\section{Reconciliations and clearance of suspense accounts advances are conducted} regularly. Advances are given to MDAs to meet various operational expenditures in districts and in the country's embassies. Details of expenditures incurred are furnished to the treasury during the year. MDAs are given a period of a month after the end of the financial year to furnish details of expenditure against advances made in the last quarter of the financial year. Accounting and reconciliation against advances is completed within two months of the end of the financial year. There are instances of uncleared balances which are brought forward, but these balances are not very significant. Dimension two is scored a B. The overall score is $\mathrm{B}$.

\section{Comparison between 2007and 2010}

This indicator has improved from D to B indicating substantial improvement in bank reconciliation.

PI-23. Availability of information on resources received by service delivery units

\begin{tabular}{|l|c|c|}
\hline Dimensions (Scoring methodology M1) & $\begin{array}{l}\text { Score } \\
\mathbf{2 0 0 7}\end{array}$ & $\begin{array}{l}\text { Score } \\
\mathbf{2 0 1 0}\end{array}$ \\
\hline (i) Data collections on resources received in cash or in-kind by service delivery units. & D & D \\
\hline
\end{tabular}


83. The MOF releases funds to MDAs for expenditures by the concerned service delivery units. However, it does not maintain a record of the service delivery units to whom funds have been released. This is currently the responsibility of the concerned ministries who are entrusted with the responsibility of developing reporting systems. The IFMIS has the capacity to monitor such details, but is not being used for this purpose at the moment. Reportedly, budget entities like schools are provided resources from line ministry programs without duly accounting for the financial or in-kind transfer. For some hospitals budget more comprehensively present overall resource availability.

\section{Comparison between 2007and 2010}

Score and performance are a $\mathrm{D}$ in both assessments.

\section{PI-24 Quality and timeliness of in-year budget reports}

\begin{tabular}{|c|c|c|c|c|}
\hline Dimensions (Scoring methodology M1) & Scor & & Scor & \\
\hline $\begin{array}{l}\text { (i) Scope of reports in terms of coverage and compatibility with budget } \\
\text { estimates. }\end{array}$ & A & \multirow{3}{*}{$\mathrm{C}+$} & A & \multirow{3}{*}{$\mathrm{C}+$} \\
\hline (ii) Timeliness of the issue of reports. & A & & $\mathrm{C}$ & \\
\hline (iii) Quality of information. & $\mathrm{C}$ & & $\mathrm{B}$ & \\
\hline
\end{tabular}

\section{Budget execution reports allow direct comparison to the presentation of}

expenditures in the budget. Data is presented by appropriation category, budget entity and line item. Both commitment and expenditure budget execution data is presented. For this reason the first dimension of this indicator, measuring coverage and compatibility with budget estimates is scored an A.

\section{Budget reports are prepared on a quarterly basis and presented to COM and} parliament within 8 weeks of the end of the quarter. Within the MOF aggregate monthly budget execution reports are generally available within 2-3 days of the end of the month. Such monthly reports could be expanded and distributed within the executive, i.e., to line ministries, agencies and the COM within say 10 days of the end of the month. Reportedly this is not done because the BFML allows for quarterly reporting and distribution within two months. It should be noted that at any point of time MOF can extract reasonably accurate budget execution information on any part of the budget it wants, so-called Crystal reports, as end of period adjustments are usually small. These are distributed to prime minister and MDA on a as requested-basis. MDA are, however, not able to monitor their budget execution data on-line in own, user-specific formats. This is an area of functionality in the FreeBalance system that could be expanded. The indicator for timeliness of budget reports is scored a C.

\section{There are no major concerns on data quality as the treasury carries out regular} reconciliations and error corrections. Transactions are subject to internal control in the treasury and audited by a commercial, external auditor. Errors can occur at the input stage in line ministries, but most of these would be detected when payment requests are made by line ministries to the treasury. The treasury does not operate automatic processing, but carries out 
a paper-based verification of each transaction. Data integrity would be further enhanced by strengthening internal control and audit in line ministries to enhance confidence on quality and timeliness of data inputting. The third dimension of quality of information is scored a B. In 2007 there were reportedly more concerns on the accuracy of data due to delays in payment instruction processing. These issues seem to have been resolved.

\section{Comparison between 2007and 2010}

The overall score for this indicator remains at the level of $\mathbf{C}+$. The lack of apparent progress may have been caused by an overly optimistic assessment in 2007. It does signal that despite the many process improvements internal to the treasury, further action is needed to fully utilize the functionality of the existing FreeBalance modules by all system-users.

\section{PI-25 Quality and timeliness of annual financial statements}

\begin{tabular}{|c|c|c|c|c|}
\hline Dimensions (Scoring methodology M1) & & 2007 & & 2010 \\
\hline (i) Completeness of the financial statements. & A & \multirow{3}{*}{$\mathrm{C}+$} & $\mathrm{C}$ & \multirow{3}{*}{$\mathrm{C}+$} \\
\hline (ii) Timeliness of submission of the financial statements. & A & & $\mathrm{A}$ & \\
\hline (iii) Accounting standards used. & $\mathrm{C}$ & & A & \\
\hline
\end{tabular}

87. Financial statements are prepared by the treasury for the whole of government, and include full information on revenues and expenditures; not all financial assets are reported on, however, and the accounting period is not fully in line with the duration of budget execution. The treasury maintains the accounts of all budget entities included in the budget. A budget execution report for the budget year is presented to parliament in preliminary form as the fourth quarterly budget report. Final accounts and a full budget execution report are submitted around September with the external auditor's report. The financial statements report on all government expenditure and revenue in several formats, including that of the budget classification and according to the functional classification. While the State's cash balances are presented as well as the holdings of the Petroleum Fund, equity holding are not reported on, nor are accounts payable and receivable. The financial statements cover the cash expenditures during the calendar year. However, for budget execution purposes the budget year is kept open much longer. For the 2009 budget it remained open till end of February 2010. In 2009, the budget year 2008 remained open till end-May 2009. This leads to discrepancy between financial statements and the full report on the budget year (which is attached as an annex to the financial statements), and decreases the comprehensiveness of the financial statements considerably. For the 2010 budget, the situation will be improved by closing of the budget year by end of January 2011. It is the intention to fully align budget execution with the calendar year by 2012 . For these reasons the completeness indicator is scored a $\mathrm{C}$. In addition to improving the comprehensiveness of the financial statements, the treasury together with the budget directorate should in the coming years also enhance considerably the narrative and the analysis in the financial statements. This would expand the function of the report from financial accountability to include administrative and political accountability. 
88. The financial statements are reported on in a timely manner; and conform to IPSAS cash basis accounting standards. The financial statements are presented to parliament within three months of the end of the fiscal year as required by the BFML. They are submitted to the external auditor within 6 months of the end of the fiscal year. This qualifies them for an A on timeliness of submission. The commercial external auditor indicates that the financial statements have been prepared in accordance with IPSAS cash basis accounting standards. The third dimension of this indicator can thus be scored an A.

\section{Comparison between 2007 and 2010}

The overall score of this indicator remains a $\mathrm{C}+$. The dimension three on accounting standards showed a significant improvement, but due to the gradual conversion to full cash accounting the completeness of financial statements has decreased for the time being.

\section{F. External Scrutiny and Audit}

\section{PI- 26 Scope, nature and follow-up of external audit}

\begin{tabular}{|c|c|c|c|c|}
\hline Dimensions (Scoring methodology M1) & Scor & & Sco & 2010 \\
\hline $\begin{array}{l}\text { (i) Scope/nature of the audit performed (including adherence to auditing } \\
\text { standards). }\end{array}$ & B & \multirow{3}{*}{$\mathrm{D}+$} & $\mathrm{C}$ & \multirow{3}{*}{$\mathrm{C}+$} \\
\hline (ii) Timeliness of submission of audit reports to legislature. & $\mathrm{B}$ & & $\mathrm{B}$ & \\
\hline (iii) Evidence of follow up on audit recommendations. & $\mathrm{D}$ & & A & \\
\hline
\end{tabular}

89. There is no independent external audit institution in TLS, but the MOF has for a number of years let a commercial external auditor audit the government accounts. The audit performed is a financial audit of all expenditure and revenue transactions over the accounts held by the treasury. The auditor does investigate process and systems issues, and reports on these, and on compliance issues, in an annual report and through a management letter. Most recommendations pertain to treasury processes. The auditor does not perform performance or proprietary audits, and does not include financial management processes in line ministries and agencies, such as internal control, procurement, and payroll. The external auditor complies with public sector audit standards for commercial auditors in Australia. These are not equivalent to INTOSAI ${ }^{17}$ standards. For example, they do not provide the same level of assurance for independence of the audit. Given the scope of the external audit, the first dimension of this indicator is scored a $\mathrm{C}$.

90. The main extrabudgetary fund, the Petroleum Fund, is audited separately by a commercial auditor. All transactions of the Petroleum Fund are audited by an external auditor, and the auditor's report is made public as an appendix to the Petroleum Fund annual report. Most autonomous agencies are, as discussed, still embedded in the management structure of central government. There are no separate audit reports on their functioning. The

\footnotetext{
${ }^{17}$ International Organization of Supreme Audit Institutions.
} 
only independent entities which undergo an external audit are the BPA and the ANP (for activities under the Timor Sea Treaty). The only public enterprise, SAMES, is not audited.

91. In the past years, the audit report and the final accounts have been submitted to parliament within 8 months of the end of the budget year. The legal limit has recently been widened to 9 months. The new BFML has set the submission of the financial statements to the HATAC (and provisionally, in its absence to the Court of Appeals) to 6 months. This will in all likelihood not lead to an earlier and separate discussion of the audit report, independent of the budget discussions. The new time limits will apply for the first time to the final accounts of the 2010 budget. The audit report is followed by a management letter of the auditor to the minister of finance summarizing the main findings and elaborating further on the recommendations. This letter is not shared with parliament, although in 2007 and 2008 the letter was published on the MOF website. The timeliness dimension of this indicator is scored a B.

92. While there is no formal response of the minister of finance to the auditor's report, there has in recent years been a serious effort to follow up on the recommendations of the external auditor. The evidence of this is reflected in work plans drawn up within MOF to address recommendations, and subsequent work programs of MOF departments such as the treasury, budget, and aid effectiveness, which reportedly have taken on board many of the recommendations of the external auditor. It would be good practice for the MOF to also send the management letter to parliament and indicate how government plans to follow-up on the recommendations in the both the audit report and management letter. The external auditor would be advised to monitor and keep track of implementation of its recommendations and publish these in the audit report. The good follow-up in practice within MOF allows this dimension to be scored an A.

\section{Comparison between 2007 and 2010}

Overall the score for this indicator has improved from a $\mathrm{D}+$ to a $\mathrm{C}+$. This must be considered a very good score given the absence of an independent, external auditor. For a substantial further improvement, broadening of the audit mandate and establishment of an independent auditor needs to be considered. 
PI-27. Legislative scrutiny of the annual budget law

\begin{tabular}{|c|c|c|c|}
\hline Dimensions (scoring methodology M1) & Sec & 2007 & Sco \\
\hline (i) Scope of the legislature's scrutiny. & $\mathrm{C}$ & \multirow{4}{*}{$\mathrm{C}+$} & $\mathrm{C}$ \\
\hline $\begin{array}{l}\text { (ii) Extent to which the legislature's procedures are well established and } \\
\text { respected. }\end{array}$ & B & & A \\
\hline $\begin{array}{l}\text { (iii) Adequacy of time for the legislature to provide a response to budget } \\
\text { proposals both the detailed estimates and, where applicable, for proposals on } \\
\text { macro-fiscal aggregates earlier in the budget preparations cycle. }\end{array}$ & B & & A \\
\hline $\begin{array}{l}\text { (iv) Rules for in-year amendments to the budget without ex ante approval by } \\
\text { the legislature. }\end{array}$ & A & & $\mathrm{C}$ \\
\hline
\end{tabular}

93. The scope of the legislature's review covers fiscal policy, and aggregate and detailed estimates of the revenue and expenditure for the coming budget year, but at the concluding stage of the budget process. This qualifies the dimension one for the score C. The draft budget is accompanied by background information that provides an overview of the economic and financial environment, revenue and expenditure projections and AAPs of line ministries. Although the documentation attached to the draft budget provides considerable information on the projected budget parameters, the analytical material included in the budget documents could be expanded, and the legislature could be involved in a debate on macro fiscal aggregates and expenditure priorities at an earlier stage in the budget cycle.

\section{Procedures for legislature review are firmly defined in the constitution and} parliament's internal regulations, and are generally respected. This means that the dimension two can be scored an A. A specialized budget committee ("Committee C") exists and plays a key role in the review of the draft budget. The committee has some support staff, but capacity for research and analysis to support reviews is limited. According to the interviews with the members of the committee, the budget documentation from the MOF has improved in recent years, and the committee can pose questions and receive more detailed information on demand. The parliamentary review is a two-step process. Only after Committee $\mathrm{C}$ reports to parliament is a plenary discussion held with prime minister and minister of finance.

95. The budget timetable leaves enough time for parliamentary scrutiny. The dimension three qualifies for the score A. According to the BFML, parliament has 2.5 months to review budget proposals (from October 15 to December 31), and this seems a reasonable amount of time for review.

96. Rules for in-year budget amendment are clearly defined in the BFML and implicitly in Petroleum Fund Law, however, they have not always been respected. Dimension four scores a C. Supplementary budgets must be approved by the parliament before moneys can be spent, and the transfers from the Petroleum Fund can only exceed the ESI of the year if the parliament is provided with estimates for the effect on ESI for coming years, and a detailed explanation of why increased spending of the petroleum wealth is in the long-term interests of TLS. Subsequently, formal approval is required of the additional 
transfer. In 2008, the supplementary budget approved by the parliament envisaged the additional transfer of US\$392.8 million $^{18}$ from the Petroleum Fund, however, the Court of Appeals decided that not more than US\$102 million could be additionally transferred to the Consolidated Fund.

Comparison between 2007 and 2010

The overall score remained $\mathrm{C}+$. In 2007 the legislature, reportedly, had only about one month to review the budget proposal.

\section{PI-28 Legislative scrutiny of external audit reports}

\begin{tabular}{|c|c|c|c|c|}
\hline Dimensions (Scoring methodology M1) & & 2007 & Scol & 10 \\
\hline Timeliness of examination of audit reports by the legislature. & A & \multirow{3}{*}{$\mathrm{D}+$} & A & \multirow{3}{*}{$\mathrm{D}+$} \\
\hline Extent of hearing on key findings undertaken by the legislature. & $\mathrm{D}$ & & $\mathrm{D}$ & \\
\hline $\begin{array}{l}\text { Issuance of the recommended actions by the legislature and } \\
\text { implementation by the executive. }\end{array}$ & $\mathrm{D}$ & & $\mathrm{C}$ & \\
\hline
\end{tabular}

\section{Parliament discusses the findings of the audit report only as part of the}

discussion on the annual budget. These discussions take place within three months of receiving the audit report. Hence the timeliness of the examination is scored an A. There are no separate hearings on the audit report, however. Parliament does sometimes send written queries to line ministries and agencies on particular issues, and prime minister, minister of finance, and line ministries can discuss issues during plenary meetings or committee meeting in the context of the overall discussion of the annual budget. The dimension on the extent of the hearings is scored a D. Only in a few cases has parliament requested action on the basis of audit findings. These requests are sometimes, but not systematically acted upon. In 2009, the government was requested to conduct a separate audit of expenditure incurred by the government during the period January to May 2009 against the budget allocations of 2008 . This request was acted upon. This dimension is scored a C. Overall the indicator remains at a $\mathrm{D}+$, although the composite score has increased somewhat.

\section{G. Donor Practices}

98. In 2007, D-1 got a score of D+. In 2010, D-1 was not rated, because of the absence of budget support from donors in the period under review.

\footnotetext{
18 The original budget included a US\$294 million transfer from the Petroleum Fund.
} 


\section{D-2. Financial information provided by donors for budgeting and reporting on project and program aid}

\begin{tabular}{|l|c|c|c|c|}
\hline Dimensions to be assessed (Scoring method M1) & \multicolumn{2}{|c|}{ Score 2007 } & \multicolumn{2}{|c|}{ Score 2010} \\
\hline $\begin{array}{l}\text { (i) Completeness and timeliness of budget estimates by donors for project } \\
\text { support. }\end{array}$ & D & D & & D + \\
\cline { 1 - 2 } $\begin{array}{l}\text { (ii) Frequency and coverage of reporting by donors on actual donors flows } \\
\text { for project support. }\end{array}$ & D & & D & \\
\hline
\end{tabular}

99. Donor funding is adequately reflected in the budget documents for the budget year. Donor funding is generally reflected in the Combined Sources Budget ${ }^{19}$ by recurrent and capital expenditures of line ministries, but is not approved by the parliament as part of the budget year appropriation. These data are compiled at stages consistent with the government's budget calendar by the NDAE created in 2008. They are comprehensive but are not fully consistent with the government's budget classification. The score is C.

100. Reporting of donors on actual flows is weak. In 2009, donors were asked to provide quarterly reports on actual disbursements but this proved to be difficult to meet in terms of timeliness, regularity, and usefulness of the data breakdown. Most donors did not manage to report in a satisfactory fashion. In 2010, the NDAE has asked donors to report on a six monthly basis. The score is $\mathrm{D}$. The overall score for the indicator is $\mathrm{D}+$

\section{D-3. Overall proportion of aid funds to central government that are managed through national procedures}

\begin{tabular}{|l|c|c|}
\hline Dimension to be assessed (Scoring method M1) & Score 2007 & Score 2010 \\
\hline $\begin{array}{l}\text { (i) Overall proportion of aid funds to central government that are managed } \\
\text { through national procedures. }\end{array}$ & $\mathrm{D}$ & $\mathrm{D}$ \\
\hline
\end{tabular}

101. External grants are managed through donor procedures. Currently the execution of donor-funded projects is mostly done through separate banking arrangements, because most donors are unwilling at this stage to use domestic systems and especially procurement is seen as a non-transparent process. The government does not have mechanisms in place that would meet donors' requirements for management of projects through national procedures. A better score than $\mathrm{D}$ would require that at least 50 percent of aid funds were managed through national procedures, which is not the case. The score is D.

\section{Comparison between 2007 and 2010}

The score and performance were the same in 2007.

\footnotetext{
${ }^{19}$ Combined Sources Budget includes funds from the State budget and external resources (donor projects).
} 


\section{Government Reform Process}

102. The government of TLS relies heavily on external support to sustain PFM systems and improve their level of performance. The MOF in particular has introduced a number of important reforms over the last three years through the WB administered Public Financial Management Capacity Building Project (PFMCBP) (see Box 1). The program (US\$6.4 million in 2009, of which US\$5.6 million is international consultants' fees) is cofinanced by an IDA grant and a Multi Donor Trust Fund. The program is an important element in the government's overall PFM reform process and has achieved a number of results, mainly in the functioning of the treasury, the Budget Directorate, the Tax and Customs Directorates, and Procurement. Nevertheless, most international advisors funded through the PFMCBP are focusing more on the daily management of PFM functions than on reform or capacity building.

103. The implementation of an IFMIS was key in many of the achievements obtained so far and will be key in future improvements, provided its development is managed carefully. Considerable resources were allocated to the purchase and development of a FreeBalance-based IFMIS system in MOF. This has proven overall beneficial to the country since it provided the ministry with a reliable tool to deliver some of its core business functions in terms of budget planning, execution, accounting and reporting, with the necessary accuracy, timeliness and controls. The IFMIS will also be key in the coming years in allowing the ministry to roll out budget management responsibilities further to line ministries and, under planned fiscal decentralization, to districts, while retaining adequate process controls, accounting functionality and supervision. In the coming years, the IFMIS needs to be more focused on the needs of the system users and become more client-friendly. At present it is still the configuration of the IFMIS system that seems to be driving business processes instead of the opposite.

104. MOF has taken a leadership role in PFM reform but overall government ownership needs to broadened. The MOF has asked WB and IMF to undertake the necessary diagnostic and analytic work to support formulation of a comprehensive multi-year PFM reform strategy covering all PFM systems. The WB was recently tasked to draft a reform strategy for the MOF, based on the mid-term review of the PFMCBP and other available diagnostics. The MOF tasked the IMF to provide an evaluation of the transparency of the overall PFM system through a fiscal transparency assessment (the fiscal ROSC), a PEFA assessment (conducted jointly with the WB and the ADB), and a strategy development for treasury functions which is expected to be conducted in August of 2010. Nevertheless, the government is lacking the necessary coordination mechanism to lead the overall reform process, and set the objectives, direction and pace of overall reforms. There is no PFM reform committee within the government, with representation of all stakeholders (PM's office, MOF, line ministries, parliament, BPA, IGO, etc.) under the leadership of the minister of finance, which would be able to play this role and liaise with the donors. While the 
minister of finance is very engaged in the reform process, and tries to interest her colleagues in the COM and other counterparts, it seems that other stakeholders are more passive.

105. Donor coordination in the PFM area is still weak and is mainly happening as part of the management of the PFMCBP. While most of the PFM reform effort is conducted through the PFMCPB, in which the WB, AusAid, the EC, Irish Aid, Norway, and New Zealand participate, this project only concerns the MOF. Other PFMrelated activities are conducted in the MOF, other ministries and institutions by the same or other donors. As with the government, there seems to be a lack of coordination on the overall PFM agenda among donors interested in supporting PFM.

\section{Box 1. The Public Financial Management Capacity Building Project}

The PFMCBP is a five-year technical assistance program supported by a grant from the IDA and a cofinancing multi-donor trust fund. The program started in late 2006, and is scheduled to end in July 2011. PFMCBP provides technical assistance to "sustainably strengthen planning, budgeting, public expenditure management and revenue administration for growth and poverty reduction, with emphasis on efficiency, effectiveness, accountability, integrity, service culture and transparency".

PFMCBP has assisted the government to take forward an important reform agenda. Key achievements include implementation of a major reorganization of the ministry of finance; strengthening public expenditure management through simplification and strengthening of treasury systems and processes and increased delegation of authority to line ministries; improved revenue management, including increased transparency in tax administration and reinforcing petroleum tax administration; and a gradual improvement in macroeconomic planning.

The MOF is responsible for the strategic management of PFMCBP, through its Senior Management Committee chaired by the minister. There is a dedicated program implementation unit responsible for day-today management of the program that has been integrated into the directorate general of corporate services. A supervisory committee of PFMCBP donors, also chaired by the minister, provides regular oversight on program implementation and achievements. All technical advisors recruited to the PFMCBP are contracted by, and accountable to the minister of finance.

Source: World Bank.

106. Capacity building issues are currently hampering further PFM reform and consolidation of recent achievements. The lack of adequate numbers of well-trained civil servants with adequate PFM skills, is the main bottleneck for further progress in PFM reform. Any future PFM reform program will have to heavily focus on the issue of staff development.

107. The government is well aware of the potential risks to the PFM reform processes, and is willing to take steps to mitigate these risks. Based on previous experiences, the following risks seem to be particularly important:

- initiation of reforms that have limited support among key stakeholders; 
- initiation of reforms that are underfunded and are not supported by adequate staff complements;

- inadequate training of staff to perform new functions; and

- failure to upgrade business processes to fully benefit from new information systems and capacities. 


\section{Annex I. PFM-PR Summary Table}

\begin{tabular}{lccc}
\hline Indicator & 2007 & 2010 & Explanation \\
& Score & Score & \\
\hline
\end{tabular}

\section{A. PFM-OUT-TURNS: Credibility of the Budget}

\begin{tabular}{|c|c|c|c|}
\hline $\begin{array}{l}\text { PI-1. Aggregate expenditure } \\
\text { out-turn compared to } \\
\text { original approved budget }\end{array}$ & $\mathrm{D}$ & $\mathrm{D}$ & $\begin{array}{l}\text { Actual primary expenditure deviated from budget estimates } \\
\text { with more than } 15 \text { percent in two of the three years considered }\end{array}$ \\
\hline $\begin{array}{l}\text { PI-2. Composition of } \\
\text { expenditure out-turn } \\
\text { compared to original } \\
\text { approved budget }\end{array}$ & N/A & A & $\begin{array}{l}\text { The variance in expenditure composition exceeded the overall } \\
\text { deviation in primary expenditure by less than } 5 \text { percent in any } \\
\text { of the last three years. }\end{array}$ \\
\hline $\begin{array}{l}\text { PI-3. Aggregate revenue } \\
\text { out-turn compared to } \\
\text { original approved budget }\end{array}$ & A & $\mathrm{C}$ & $\begin{array}{l}\text { Actual domestic revenue collection was below } 92 \text { percent of } \\
\text { budgeted domestic revenue estimates in one of the last three } \\
\text { years. }\end{array}$ \\
\hline $\begin{array}{l}\text { PI-4. Stock and monitoring } \\
\text { of expenditure payment } \\
\text { arrears }\end{array}$ & D & $\mathrm{D}+$ & $\begin{array}{l}\text { Anecdotal information indicate that the stock of payment } \\
\text { arrears has generally been very low (below } 2 \text { percent of total } \\
\text { expenditure), but no reliable data exist, nor are periodic } \\
\text { surveys carried out. }\end{array}$ \\
\hline
\end{tabular}

\section{B. KEY CROSSCUTTING ISSUES: Comprehensiveness and Transparency}

$\begin{array}{lll}\begin{array}{l}\text { PI-5. Classification of the } \\ \text { budget }\end{array} & \text { D } \quad \text { B } & \begin{array}{l}\text { The chart of accounts used for budget management contains an } \\ \text { organizational, economic, and a partial functional } \\ \text { classification. The program classification is not well- } \\ \text { developed and not used for budget management. }\end{array}\end{array}$

PI-6. Comprehensiveness of B A information included in budget documentation

PI-7. Extent of unreported government operations

PI-8. Transparency of intergovernmental fiscal relations PI-9. Oversight of aggregate fiscal risk from other public sector entities

PI-10. Public access to key fiscal information
B A The budget documentation does include neither information on financial assets nor explanation of budget implications of new policy initiatives.

A D + The level of unreported extra-budgetary expenditure appears to be low and does not exceed one percent of the budget expenditure. Few donor funded projects implemented via the line ministries' accounts in the commercial banks are neither recorded nor included in the government financial reports.

N/A N/A There is currently no subnational government in TLS.

A D Public entities which are in fact autonomously managed (SAMES, IMfTL, Lottery, ANP) are not reported in the budget documentation and there is neither annual monitoring, supervision nor consolidation of overall fiscal risks.

C B The government publishes the annual budget on the MOF website at the time of presentation to parliament. External audit reports are posted on the website as they are presented to parliament. Tender awards and resources available to primary service units are not published systematically. 


\section{BUDGET CYCLE \\ C(i) Policy-Based Budgeting}

PI-11. Orderliness and participation in the annual budget process

PI-12. Multiyear perspective in fiscal planning, expenditure policy, and budgeting
B C + There is a clear and widely known budget calendar and a budget circular to guide MDAs in preparing budget submissions, however it does not allow a reasonable amount of time to complete the capital budget submissions and no ceilings are included for the capital budget. The budget has been approved before the start of the financial year during the two of last 3 years.

B $+\quad$ D $+\quad$ Multi-year perspective of fiscal planning is at an initial stage.

A few sector strategies which are costed are not integrated into strategic plans, and are not consistent with medium-term forecasts. Investment decisions are not based on sector strategies, and there is no link between capital expenditure and medium-term recurrent estimates.

\section{C(ii) Predictability and Control in Budget Execution}

PI-13. Transparency of taxpayer obligations and liabilities

PI-14. Effectiveness of measures for taxpayer registration and tax assessment

PI-15. Effectiveness in collection of tax payments

PI-16. Predictability in the availability of funds for commitment of expenditures

PI-17. Recording and management of cash balances, debt, and guarantees
D+ C Determination of tax liabilities is clear, but tax collection procedures are still complex and gives tax officers a fair amount of discretionary powers. Taxpayers have some access to information on tax liabilities, but access to information on administrative procedures is much more difficult.

Administrative procedure for tax appeals is in place but is not efficient and independent enough.

C+ $\quad$ D $+\quad$ The taxpayer registration system has been introduced, but has not yet been linked with other databases. Penalties for noncompliance exist, but substantial changes are necessary to have a real impact. There is no comprehensive and documented audit plan and audits are not conducted according to clear risk criteria.

D + D $+\quad$ The overall amount of tax arrears is fairly insignificant Revenue collections are transferred to the treasury's main account daily. Aggregate reporting on tax assessments, collections, arrears and transfers to (and receipts by) the treasury is done with more than three months delay and is not reconciled.

D $\quad$ B $+\quad$ Cash flow forecasts are made at the start of the year and reviewed every quarter. Changes are generally as a consequence of an increase in the budget outlay because of a midyear supplementary budget.

A C Cash balances are consolidated and calculated daily. However, substantial government cash balances, both under treasury or line ministry control, are retained in bank accounts in commercial banks which do not form part of the consolidated cash balances of government. 


\begin{tabular}{|c|c|c|}
\hline $\begin{array}{l}\text { PI-18. Effectiveness of } \\
\text { payroll controls }\end{array}$ & $\begin{array}{ll}\mathrm{D}+ & \mathrm{D}+\end{array}$ & $\begin{array}{l}\text { The treasury makes changes to its payroll database only on the } \\
\text { basis of inputs received from MDAs or the Public Service } \\
\text { Commission, because personnel records and payroll database } \\
\text { is not reconciled in any systematic way. Occasionally, changes } \\
\text { are made with a delay of up to three months. No audit of } \\
\text { payroll has taken place for many years now. }\end{array}$ \\
\hline
\end{tabular}

PI-19. Competition, value for money and controls in procurement

PI-20. Effectiveness of internal controls for nonsalary expenditure

PI-21. Effectiveness of internal audit

C(iii) Accounting, Recording and Reporting

PI-22. Timeliness and

D B regularity of accounts reconciliation

PI-23. Availability of

D D information on resources received by service delivery units

PI-24. Quality and timeliness of in-year budget reports

PI-25. Quality and timeliness of annual financial statements
B C While the legal framework for procurement recommends the use of competitive bidding processes, there is much leeway in practice for use of less competitive methods, and however no functioning monitoring mechanism at the center of government to track the relative use of competitive bidding. There is no external oversight body, but reasonable administrative appeals process exists.

D+ $\quad$ C $+\quad$ Comprehensive expenditure commitment controls are in place and effectively limit commitments to actual cash availability and approved budget allocation. Staff in the MDAs is still not very conversant with rules and procedures for internal control.

D D The internal audit capacity is weak, and reports are infrequent.
$\mathrm{C}+\quad \mathrm{C}+$

Budget execution reports allow direct comparison to the presentation of expenditures in the budget both on commitment and expenditure basis. Budget reports are prepared on a quarterly basis and presented to COM and parliament within 8 weeks of the end of the quarter. MDAs, however, are not able to monitor their budget execution data on-line in user-friendly formats.

$\mathrm{C}+\quad \mathrm{C}+$

Bank reconciliations with the TSA with the BPA take place within two weeks of the close of every month, but reconciliations and clearance of suspense accounts advances are completed within two months of the end of the financial year.

Information regarding further release of funds by line ministries to service delivery units is not maintained by the MOF. The IFMIS has the capacity to monitor such details, but is not being used for this purpose at the moment.

Financial Statements include full information on revenues and expenditures; not all financial assets are reported on and the accounting period is not fully in line with the duration of budget execution. The financial statements have been prepared in accordance with IPSASB cash basis accounting standards. 


\begin{tabular}{|c|c|c|c|}
\hline $\begin{array}{l}\text { PI-26. Scope, nature, and } \\
\text { follow-up of external audit }\end{array}$ & $\mathrm{D}+$ & $\mathrm{C}+$ & $\begin{array}{l}\text { There is no independent external auditor, but a commercial } \\
\text { external auditor audits the government accounts. The audit } \\
\text { performed is a financial audit of all expenditure and revenue } \\
\text { transactions over the accounts held by the treasury. The auditor } \\
\text { does investigate process and systems issues, and reports on } \\
\text { these, and on compliance issues, in an annual report and } \\
\text { through a management letter. }\end{array}$ \\
\hline $\begin{array}{l}\text { PI-27. Legislative scrutiny } \\
\text { of the annual budget law }\end{array}$ & $\mathrm{C}+$ & $\mathrm{C}+$ & $\begin{array}{l}\text { The scope of the legislature's review covers fiscal policy, and } \\
\text { aggregate and detailed estimates of the revenue and } \\
\text { expenditure for the coming budget year, but at the concluding } \\
\text { stage of the budget process. Procedures for legislature review } \\
\text { are firmly defined and leave enough time ( } 2.5 \text { months) for } \\
\text { parliamentary scrutiny. In-year budget amendments are clearly } \\
\text { stated in the BFML, but they have not always been respected. }\end{array}$ \\
\hline
\end{tabular}

PI-28. Legislative scrutiny $\quad$ D $+\quad$ D $+\quad$ Parliament discusses the findings of the audit report only as of external audit reports part of the discussion on the annual budget. Only in a few cases has parliament requested action on the basis of audit findings. These request are sometimes, but not systematically acted upon.

\section{Donor Practices}

\begin{tabular}{lccl}
\hline $\begin{array}{l}\text { D-1. Predictability of direct } \\
\text { budget support }\end{array}$ & D + & N/A & $\begin{array}{l}\text { No direct budget support from donors in the period under } \\
\text { review. }\end{array}$ \\
$\begin{array}{l}\text { D-2. Financial information } \\
\text { provided by donors for } \\
\text { budgeting and reporting on } \\
\text { project and program aid }\end{array}$ & D & D + & $\begin{array}{l}\text { Donor funding is reflected in the combined sources budget by } \\
\text { recurrent and capital expenditures of line ministries, but } \\
\text { reporting of donors on actual disbursements is weak. }\end{array}$ \\
$\begin{array}{l}\text { D-3. Proportion of aid that } \\
\text { is managed by use of } \\
\text { national procedures }\end{array}$ & D & D & $\begin{array}{l}\text { Currently the execution of donor funded projects is mostly } \\
\text { done through separate banking arrangements. }\end{array}$ \\
\hline
\end{tabular}




\section{Annex II. Background Documents and Previous Analytical Work}

1. Budget documentation in English for 2007, 2008, 2009, and 2010.

2. Budget Execution Reports for 2007, 2008, and 2009.

3. Various legal documents: the Budget and Financial Management Law, the Taxes and Duties Act, Procurement Decree Laws, Petroleum Act, Internal Regulations of Parliament, Constitution of 2002.

4. Summary of Strategic Development Plan, 2010.

5. Strategic Plan of the MOF.

6. Website of the MOF: www.mof.gov.tl.

7. Quarterly Project Management Report of the PFMCBP, World Bank.

8. Various IMF document: Timor-Leste Fiscal ROSC (pending); Democratic Republic of Timor Leste: Article IV Consultation - Staff Report 2007, 2008, and 2009. 


\section{Annex III. Calculation Sheet for PFM Performance Indicator PI-2}

Step 1: Enter the three fiscal years used for assessment in Table 7.

Step 2: Enter budget and actual expenditure data for each of the three years in Tables 8, 9, and 10 respectively, for the largest 20 budget heads (reference year 2009).

Step 3: Read the results for each of the three years for each indicator in Table 11.

Step 4: Go to the scoring tables for indicators PI-1 and PI-2 respectively in the Performance Measurement Framework in order to decide the score (A, B, C or D).

Table 7. Fiscal Years for Assessment

\begin{tabular}{ll}
\hline Year 1 $=$ & 2007 \\
Year 2 $=$ & 2008 \\
Year 3 $=$ & 2009 \\
\hline
\end{tabular}

Table 8. Data for 2007

\begin{tabular}{lrrrrr}
\hline \multicolumn{1}{c}{ Functional head } & \multirow{2}{*}{ Budget } & Actual & Difference & Absolute & Percent \\
& & & & & \\
\hline 1. Ministry of Infrastructure & 10,353 & 3,220 & $-7,133$ & 7,133 & $68.9 \%$ \\
2. Whole of Government & 26,070 & 15,738 & $-10,332$ & 10,332 & $39.6 \%$ \\
3. Ministry of Social Solidarity & 6,785 & 3,757 & $-3,028$ & 3,028 & $44.6 \%$ \\
4. Ministry of Defense & 11,537 & 5,820 & $-5,717$ & 5,717 & $49.6 \%$ \\
5. Ministry of Education & 10,928 & 10,086 & -842 & 842 & $7.7 \%$ \\
6. Ministry of Tourism, Industry & 7,587 & 1,410 & $-6,177$ & 6,177 & $81.4 \%$ \\
7. Ministry of Agriculture & 5,376 & 2,717 & $-2,659$ & 2,659 & $49.5 \%$ \\
8. Prime Minister Cabinet & 7,737 & 4,594 & $-3,143$ & 3,143 & $40.6 \%$ \\
9. Ministry of Health & 6,939 & 5,278 & $-1,661$ & 1,661 & $23.9 \%$ \\
10. Ministry State Administration & 3,075 & 1,946 & $-1,129$ & 1,129 & $36.7 \%$ \\
11. Ministry of Justice & 1,903 & 1,156 & -747 & 747 & $39.3 \%$ \\
12. Ministry of Foreign Affairs & 2,686 & 2,234 & -452 & 452 & $16.8 \%$ \\
13. EDTL & & & 0 & 0 & \\
14. National Parliament & 1,496 & 1,027 & -469 & 469 & $31.4 \%$ \\
15. Ministry of Finance & 2,669 & 2,049 & -620 & 620 & $23.2 \%$ \\
16. APORTIL & & & 0 & 0 & \\
17. President of Republic & 900 & 805 & -95 & 95 & $10.6 \%$ \\
18. Ministry of Economy & 784 & 572 & -212 & 212 & $27.0 \%$ \\
19. Public Broadcasting Service & 754 & 492 & -262 & 262 & $34.7 \%$ \\
20. Commission for Elections & 87 & 83 & -4 & 4 & $4.6 \%$ \\
21. Sum of Rest & 8,563 & 1,193 & $-7,370$ & 7,370 & $86.1 \%$ \\
Total expenditure & $\mathbf{1 1 6 , 2 2 9}$ & $\mathbf{6 4 , 1 7 7}$ & $\mathbf{- 5 2 , 0 5 2}$ & $\mathbf{5 2 , 0 5 2}$ & $\mathbf{4 4 . 8 \%}$ \\
Composition variance & $\mathbf{1 1 6 , 2 2 9}$ & $\mathbf{6 4 , 1 7 7}$ & & $\mathbf{5 2 , 0 5 2}$ & $\mathbf{4 4 . 8 \%}$ \\
\hline
\end{tabular}


Table 9. Data for 2008

\begin{tabular}{lrrrrr}
\hline \multicolumn{1}{c}{ Functional head } & \multirow{2}{*}{ Budget } & Actual & Difference & Absolute & Percent \\
& & & & & \\
\hline 1. Ministry of Infrastructure & 58,885 & 68,393 & 9,508 & 9,508 & $16.1 \%$ \\
2. Whole of Government & & & & & 157.3 \\
& 44,161 & 113,614 & 69,453 & 69,453 & $\%$ \\
3. Ministry of Social Solidarity & 14,793 & 24,449 & 9,656 & 9,656 & $65.3 \%$ \\
4. Ministry of Defense & 37,569 & 40,173 & 2,604 & 2,604 & $6.9 \%$ \\
5. Ministry of Education & 45,280 & 44,866 & -414 & 414 & $0.9 \%$ \\
6. Ministry of Tourism, Industry & 7,900 & 9,206 & 1,306 & 1,306 & $16.5 \%$ \\
7. Ministry of Agriculture & 16,668 & 27,263 & 10,595 & 10,595 & $63.6 \%$ \\
8. Prime Minister Cabinet & 38,430 & 61,518 & 23,088 & 23,088 & $60.1 \%$ \\
9. Ministry of Health & 23,983 & 27,578 & 3,595 & 3,595 & $15.0 \%$ \\
10. Ministry State Administration & 11,991 & 12,983 & 992 & 992 & $8.3 \%$ \\
11. Ministry of Justice & 7,211 & 9,221 & 2,010 & 2,010 & $27.9 \%$ \\
12. Ministry of Foreign Affairs & 7,000 & 8,853 & 1,853 & 1,853 & $26.5 \%$ \\
13. EDTL & & & 0 & 0 & \\
14. National Parliament & & & 0 & 0 & \\
15. Ministry of Finance & 6,785 & 6,942 & 157 & 157 & $2.3 \%$ \\
16. APORTIL & 8,152 & 10,172 & 2,020 & 2,020 & $24.8 \%$ \\
17. President of Republic & 4,217 & 4,978 & 761 & 761 & $18.0 \%$ \\
18. Ministry of Economy & 6,580 & 6,711 & 131 & 131 & $2.0 \%$ \\
19. Public Broadcasting Service & 1,904 & 2,018 & 114 & 114 & $6.0 \%$ \\
20. Commission for Elections & 1,604 & 1,594 & -10 & 10 & $0.6 \%$ \\
21. Sum of Rest & 4,640 & 3,953 & -687 & 687 & $14.8 \%$ \\
Total expenditure & $\mathbf{3 4 7 , 7 5 3}$ & $\mathbf{4 8 4 , 4 8 5}$ & $\mathbf{1 3 6 , 7 3 2}$ & $\mathbf{1 3 6 , 7 3 2}$ & $\mathbf{3 9 . 3 \%}$ \\
Composition variance & $\mathbf{3 4 7 , 7 5 3}$ & $\mathbf{4 8 4 , 4 8 5}$ & & $\mathbf{1 3 8 , 9 5 4}$ & $\mathbf{4 0 . 0 \%}$ \\
\hline
\end{tabular}


Table 10. Data for 2009

\begin{tabular}{lrrrrr}
\hline \multicolumn{1}{c}{ Functional head } & Budget & Actual & Difference & Absolute & Percent \\
& & & & & \\
\hline 1. Ministry of Infrastructure & 129,649 & 112,855 & $-16,794$ & 16,794 & $13.0 \%$ \\
2. Whole of Government & 82,019 & 72,851 & $-9,168$ & 9,168 & $11.2 \%$ \\
3. Ministry of Social Solidarity & 74,523 & 72,883 & $-1,640$ & 1,640 & $2.2 \%$ \\
4. Ministry of Defense & 65,585 & 59,728 & $-5,857$ & 5,857 & $8.9 \%$ \\
5. Ministry of Education & 62,570 & 60,458 & $-2,112$ & 2,112 & $3.4 \%$ \\
6. Ministry of Tourism, Industry & 61,008 & 42,179 & $-18,829$ & 18,829 & $30.9 \%$ \\
7. Ministry of Agriculture & 33,914 & 33,270 & -644 & 644 & $1.9 \%$ \\
8. Prime Minister Cabinet & 33,454 & 29,083 & $-4,371$ & 4,371 & $13.1 \%$ \\
9. Ministry of Health & 32,893 & 28,881 & $-4,012$ & 4,012 & $12.2 \%$ \\
10. Ministry State Administration & 16,951 & 15,862 & $-1,089$ & 1,089 & $6.4 \%$ \\
11. Ministry of Justice & 12,784 & 10,630 & $-2,154$ & 2,154 & $16.8 \%$ \\
12. Ministry of Foreign Affairs & 11,326 & 10,219 & $-1,107$ & 1,107 & $9.8 \%$ \\
13. EDTL & 10,999 & 11,359 & 360 & 360 & $3.3 \%$ \\
14. National Parliament & 9,583 & 8,027 & $-1,556$ & 1,556 & $16.2 \%$ \\
15. Ministry of Finance & 8,972 & 7,917 & $-1,055$ & 1,055 & $11.8 \%$ \\
16. APORTIL & 5,933 & 4,970 & -963 & 963 & $16.2 \%$ \\
17. President of Republic & 5,533 & 5,066 & -467 & 467 & $8.4 \%$ \\
18. Ministry of Economy & 5,255 & 5,073 & -182 & 182 & $3.5 \%$ \\
19. Public Broadcasting Service & 3,935 & 3,540 & -395 & 395 & $10.0 \%$ \\
20. Commission for Elections & 3,693 & 2,931 & -762 & 762 & $20.6 \%$ \\
21. Sum of Rest & 10,294 & 7,256 & $-3,038$ & 3,038 & $29.5 \%$ \\
Total expenditure & $\mathbf{6 8 0 , 8 7 3}$ & $\mathbf{6 0 5 , 0 3 8}$ & $-\mathbf{7 5 , 8 3 5}$ & $\mathbf{7 5 , 8 3 5}$ & $\mathbf{1 1 . 1 \%}$ \\
Composition variance & $\mathbf{6 8 0 , 8 7 3}$ & $\mathbf{6 0 5 , 0 3 8}$ & & $\mathbf{7 6 , 5 5 5}$ & $\mathbf{1 1 . 2 \%}$ \\
\hline
\end{tabular}

Table 11. Results Matrix

\begin{tabular}{cccc}
\hline Year & $\begin{array}{c}\text { For PI-1 } \\
\text { Total exp. deviation }\end{array}$ & Total exp. variance & $\begin{array}{c}\text { For Pl-2 } \\
\text { Variance in excess } \\
\text { of total deviation }\end{array}$ \\
\hline 2007 & $44.8 \%$ & $44.8 \%$ & $0.0 \%$ \\
2008 & $39.3 \%$ & $40.0 \%$ & $0.6 \%$ \\
2009 & $11.1 \%$ & $11.2 \%$ & $0.1 \%$ \\
\hline
\end{tabular}

